\title{
Immunesenescence: A Predisposing Risk Factor for the Development of COVID-19?
}

\author{
Jon Hazeldine ${ }^{1,2}$ and Janet M. Lord ${ }^{1,2,3 *}$ \\ ${ }^{1}$ Medical Research Council-Versus Arthritis Centre for Musculoskeletal Ageing Research, Institute of Inflammation and \\ Ageing, University of Birmingham, Birmingham, United Kingdom, ${ }^{2}$ National Institute for Health Research Surgical \\ Reconstruction and Microbiology Research Centre, Queen Elizabeth Hospital Birmingham, Birmingham, United Kingdom, \\ ${ }^{3}$ National Institute for Health Research Birmingham Biomedical Research Centre, University Hospital Birmingham National \\ Health Service Foundation Trust and University of Birmingham, Birmingham, United Kingdom
}

\section{OPEN ACCESS}

Edited by:

Moisés Evandro Bauer, Pontifical Catholic University of Rio Grande do Sul, Brazil

Reviewed by: Sara Hamilton University of Minnesota Twin Cities,

United States

Florencia Maria Barbé-Tuana, Pontifical Catholic University of Rio

Grande do Sul, Brazil

*Correspondence: Janet M. Lord j.m.lord@bham.ac.uk

Specialty section:

This article was submitted to Immunological Memory, a section of the journal Frontiers in Immunology

Received: 17 June 2020 Accepted: 28 August 2020 Published: 06 October 2020

Citation:

Hazeldine J and Lord JM (2020) Immunesenescence: A Predisposing Risk Factor for the Development of COVID-19?

Front. Immunol. 11:573662. doi: 10.3389/fimmu.2020.573662
Bearing a strong resemblance to the phenotypic and functional remodeling of the immune system that occurs during aging (termed immunesenescence), the immune response to severe acute respiratory syndrome coronavirus 2 (SARS-CoV-2), the causative agent of Coronavirus disease 2019 (COVID-19), is characterized by an expansion of inflammatory monocytes, functional exhaustion of lymphocytes, dysregulated myeloid responses and the presence of highly activated senescent T cells. Alongside advanced age, male gender and pre-existing co-morbidities [e.g., obesity and type 2 diabetes (T2D)] are emerging as significant risk factors for COVID-19. Interestingly, immunesenescence is more profound in males when compared to females, whilst accelerated aging of the immune system, termed premature immunesenescence, has been described in obese subjects and T2D patients. Thus, as three distinct demographic groups with an increased susceptibility to COVID-19 share a common immune profile, could immunesenescence be a generic contributory factor in the development of severe COVID-19? Here, by focussing on three key aspects of an immune response, namely pathogen recognition, elimination and resolution, we address this question by discussing how immunesenescence may weaken or exacerbate the immune response to SARS-CoV-2. We also highlight how aspects of immunesenescence could render potential COVID-19 treatments less effective in older adults and draw attention to certain therapeutic options, which by reversing or circumventing certain features of immunesenescence may prove to be beneficial for the treatment of groups at high risk of severe COVID-19.

Keywords: aging, COVID-19, immunesenescence, immune dysfunction, inflammaging, SARS-Cov_2

\section{INTRODUCTION}

Severe acute respiratory syndrome coronavirus 2 (SARS-CoV-2) is a novel highly-infectious betacoronavirus originally found in Wuhan, China in December 2019 (1). Transmitted by direct contact with infected individuals, contaminated surfaces or via respiratory droplets, SARS-CoV-2 is the causative agent of Coronavirus disease 2019 (COVID-19), which as of June 2020 had infected over 7 million people resulting in over 400,000 deaths (2). Whilst for the majority of individuals COVID-19 is a self-resolving mild to moderate respiratory tract infection, $\sim 20 \%$ of infected patients develop severe respiratory complications (e.g., dyspnea and pneumonia), which, 
in extreme cases $(\sim 5 \%)$, progress to acute respiratory distress syndrome (ARDS), respiratory failure, organ damage, and death (3-6).

Epidemiological analyses of COVID-19 outbreaks have revealed the disease to be highly prevalent amongst older adults, with one study of 1,591 patients reporting $87 \%$ of cases were in adults aged 51 years and over $(7,8)$. Furthermore, older adults are more prone to developing severe COVID-19 and its associated poor outcomes $(4,6,9-15)$. For example, 91 and $81 \%$ of COVID19 related deaths have occurred in people aged 65 years and over in the UK and USA respectively, with the majority of deaths occurring in those aged 85 years and over $(16,17)$. Moreover, the recovery times of older adults who survive COVID-19 are more protracted, involving more serious clinical manifestations that often require hospitalization and prolonged therapy $(10,14,18)$.

The scientific community has moved rapidly to gain an understanding of the immune response to SARS-CoV-2 and how it influences patient outcome. Summarized recently by Vabret et al. (19) the current literature details a hyper-inflammatory state in severe COVID-19 patients that is characterized by a sustained raised level of pro-inflammatory cytokines such as interleukin (IL)-6, expansion of inflammatory monocytes and $\mathrm{T}$ cells, dysregulated myeloid responses, functional exhaustion of lymphocytes and impaired innate immune function. This immunological profile bears a strong resemblance to the remodeling of the immune system that occurs during physiological aging. Termed immunesenescence, immune aging is associated with marked alterations in the composition, phenotype and functional responsiveness of the innate and adaptive arms of the immune system that compromises the older adults ability to combat infections allowing for pathogen dissemination in a vicious cycle that leads to further inflammation and ultimately tissue damage. Furthermore, aging is accompanied by a state of chronic low-grade systemic inflammation, termed inflammaging, meaning older patients start with a higher inflammation status prior to infection. Immunesenescence is viewed as a major contributory factor in the increased susceptibility of older adults to infection $(20,21)$ as well as their poor vaccination responses (22). In addition to older adults, males $(3,4,6,13,23,24)$ as well as patients with pre-existing co-morbidities such as diabetes $(4,13-15,25)$ and obesity $(11,24,26-29)$ are at an increased risk of severe COVID-19.

Immunologically, immunesenescence and inflammaging appear to be more profound in older males when compared to females $(30,31)$, whilst an accelerated aging phenotype, termed premature immunesenescence has been described in obese subjects and patients with type 2 diabetes (T2D) (32-34). Although $85-90 \%$ of T2D patients are overweight or obese, not all adults who are obese develop T2D and most studies suggest the prevalence is below $50 \%$ (35). For this reason, we have considered three distinct demographic groups with an increased susceptibility to COVID-19 that appear to share a common immune profile, posing the question could immunesenescence be a generic contributory factor in the development of severe COVID-19? Here, by focussing on three key aspects of an immune response, namely pathogen recognition, elimination and resolution, we will address this question by discussing how immunesenescence may weaken or exacerbate the immune response to SARS-CoV-2. We also highlight how aspects of immunesenescence could render potential COVID-19 treatments less effective in older adults and draw attention to certain therapeutic options, which by reversing or circumventing certain features of immunesenescence may prove to be beneficial for the treatment of groups at high risk of severe COVID-19.

\section{PATHOGEN RECOGNITION}

\section{Pathogen Recognition Receptor Expression and the Early Anti-viral Response}

Comprised of four different families, namely the toll-like receptors (TLRs), retinoic acid-inducible gene (RIG)-I-like receptors (RLRs), nucleotide-binding oligomerization domainlike receptors (NLRs) and the C-type lectin receptors (CLRs), pathogen recognition receptors (PRRs) are evolutionary conserved germline-encoded receptors responsible for the early detection of invading pathogens. Located at the cell surface, in endosomes and in the cytosol, PRRs are expressed predominantly by cells of the innate immune system, in particular monocytes and dendritic cells (DCs). As a single-stranded RNA virus, detection and initiation of the immune response against SARSCoV-2 will be mediated by the RNA-sensing endosomal PRRs TLR 3, 7 and 8, and the cytoplasmic-residing RLRs and NLRs.

Ligation of PRRs activates interferon regulatory factors (IRFs), a family of transcription factors that drive the production of type I $(\alpha / \beta)$ and type III $(\gamma)$ interferons (IFNs) (36). By inhibiting viral replication, enhancing innate immune responses and modulating $\mathrm{T}$ cell expansion and memory formation (37), IFNs provide strong anti-viral effects. SARS-CoV-2 appears particularly sensitive to IFNs, with in vitro culture studies revealing viral replication in kidney epithelial cells and primary human intestinal epithelial cells is potently inhibited by type I and type III IFNs, respectively $(38,39)$. In one of the few studies to have investigated the IFN response to SARS-CoV-2 in patients $(40,41)$, Hadjadj et al. identified a distinct type I IFN signature in severe COVID-19 patients (40). Compared to individuals with mild to moderate disease, critically ill patients presented with marked downregulation of IFN-stimulated genes in whole blood leukocytes, significantly lower plasma levels of IFN- $\alpha 2$ and reduced IFN activity in serum (40).

Studies that have examined the effect of age on the expression of RNA-sensing PRRs have reported significantly reduced expression of TLRs 3, 7, and 8 in myeloid DCs (mDCs) or plasmacytoid DCs (pDCs) isolated from older adults $(42,43)$. Accompanying these changes in PRR expression is an age-related impairment in the generation of type I and III IFNs (44). pDCs or monocytes from older adults secrete significantly lower amounts of IFN $\alpha, \beta$, or $\gamma$ in response to specific ligation of TLRs $7 / 8$ and RIG-I, with the reduction in IFN $\alpha$ and $\beta$ synthesis post-RIGI activation attributed to impaired activation of IRFs (43, 4547). Furthermore, and of particular importance in the context of SARS-CoV-2, age-related impairments in type I IFN production 
have been described for monocytes and pDCs challenged with influenza A virus and West Nile virus (WNV) (42, 47-50), two RNA viruses that also cause significant morbidity and mortality in older adults (51-53). As prompt and efficient type I IFN responses are critical for preventing poor outcome following coronavirus infections $(54,55)$, an age-related impairment in IFN production may result in more robust virus replication and higher viral loads. On this note, it has been suggested that COVID-19 patients with type I IFN deficiency, a criterion we propose older adults would fulfill, may benefit from IFN $\alpha$ or $\beta$ supplementation (40). In an open-label, randomized, phase 2 trial in COVID-19 patients, Hung and colleagues demonstrated that, when compared to anti-viral drug treatment alone, a combined therapy of anti-viral drugs and IFN- $\beta$ significantly shortened the duration of viral shedding, time to symptom resolution and length of hospital stay in patients with mild to moderate disease (56). Whilst this therapeutic approach is worthy of consideration for geriatric COVID-19 patients, it should be noted that in vitro studies with monocytes from older adults have demonstrated reduced up-regulation of IFN-stimulated genes following influenza A virus challenge (47). Thus, increasing type I IFN levels in older adults via IFN supplementation may be offset by an age-related impairment in IFN responsiveness.

Ligation of PRRs also triggers the secretion of proinflammatory cytokines via the activation of nuclear factor kappa B (NF-кB) and mitogen activated protein kinase (MAPK) signaling pathways. Compared to those with mild-to-moderate disease, patients with severe COVID-19 infection present with significantly elevated circulating concentrations of a range of proinflammatory cytokines such as IL-6 and tumor necrosis factoralpha (TNF- $\alpha)$ (57-61). Although not observed in all studies $(43,62)$, the majority of groups that have investigated cytokine production triggered by RNA-sensing PRRs have found this function is maintained with age $(42,43,46,47,62)$. For example, in response to stimulation with TLR3, TLR 7/8 and RIG-I specific ligands, as well as influenza A virus, $\mathrm{mDCs}$ or monocytes isolated from young and older adults generate comparable levels of TNF$\alpha$, IL- 6 and/or IL-12 $(42,43,46,47,62)$. In the context of COVID19 , these data imply that the pro-inflammatory cytokine response to SARS-CoV-2 elicited by monocytes and mDCs would be similar across different age groups. However, this may not be the case for patients with pre-existing co-morbidities. For instance, compared to normal-weight controls, monocytes isolated from obese subjects generate significantly greater amounts of TNF- $\alpha$ and CCL5 following stimulation with viral ssRNA (63), whilst in monocytes from T2D patients, basal expression of components of the TLR signaling pathway such as the adaptor proteins MyD88 and TRIF as well as the p65 subunit of NF- $\kappa \mathrm{B}$ are significantly increased (64). Thus, we propose that this remodeling of innate immune cells in obese and T2D patients would lead to a more robust pro-inflammatory response to SARS-CoV-2 when compared to that of healthy age-matched controls, culminating in greater systemic inflammation and more severe disease.

Generated via the activation of the NLRP3 inflammasome, a multi-subunit complex comprising of the NLR protein NLRP3, the adaptor protein ASC and caspase- 1 , IL- $1 \beta$ promotes anti-microbial resistance via the modulation of innate and adaptive immune responses (65). However, if dysregulated, production of this pro-inflammatory cytokine can promote lung injury and severe pulmonary fibrosis $(66,67)$. Coinciding with elevated plasma levels of IL-1 $\beta$ (3), single cell transcriptomic analysis of peripheral blood mononuclear cells (PBMCs) has shown a greater abundance of classical CD $14^{++} \mathrm{CD}^{+} 6^{-} \mathrm{IL} 1 \beta^{+}$ monocytes in COVID-19 patients when compared to healthy controls (HCs) (68), whilst analysis of RNA extracted from whole blood found increased IL- $1 \beta$ gene expression preceded a decline in respiratory function (69). In terms of patient groups at high risk of severe COVID-19, significantly increased NLRP3 expression and ssRNA-induced IL-1 $\beta$ generation has been reported for monocytes and monocyte-derived macrophages isolated from T2D patients and obese subjects, respectively (63, $70,71)$, suggesting potential exaggeration of inflammasomemediated immune responses to SARS-CoV-2 in these cohorts. Conversely, aging appears to be associated with impaired activation of the inflammasome. Investigated primarily in animal models, significantly reduced inducible expression of NLRP3, ASC and/or caspase-1 has been described in lung homogenates, macrophages and/or DCs from aged mice, with these changes in expression resulting in decreased synthesis of IL-1 $\beta$ upon stimulation (72-74). Highlighting the importance of the inflammasome in host protection, models of influenza infection and secondary Streptococcus pneumoniae infection have shown the age-associated decrease in NLRP3 inflammasome expression and activity results in impaired cell infiltration to sites of infection, increased pathogenic load in the lung and higher rates of morbidity and mortality $(72,74)$. In terms of human aging and its impact on the inflammasome, no change (47) or a significant reduction (45) in IL-1 $\beta$ production by monocytes challenged with influenza A virus or TLR 7/8 ligands, respectively has been reported. Given the importance of the inflammasome in host defense against viral infections $(75,76)$, we suggest that the older COVID-19 patient with no pre-existing comorbidities would elicit an impaired inflammasome-mediated immune response to SARS-CoV-2 that would increase their susceptibility to severe disease.

\section{PATHOGEN ELIMINATION}

\section{Neutrophils}

Currently, few studies have reported upon the neutrophil response to SARS-CoV-2. These studies have shown neutrophilia $(3,4)$, an elevated neutrophil-to-lymphocyte ratio $(60,61,77-79)$ and neutrophil infiltration in the lungs $(80,81)$ to be features of severe COVID-19 and poor patient outcomes. In the only laboratory-based study, Zuo et al., using cell-free DNA (cfDNA), myeloperoxidase-DNA complexes and citrullinated histone $\mathrm{H} 3$ as surrogate markers of in vivo neutrophil extracellular trap (NET) formation, reported elevated levels of all three markers in serum samples obtained from hospitalized COVID-19 patients when compared to HCs (82). Significantly higher cfDNA and myeloperoxidase-DNA complexes were recorded in those who required mechanical ventilation, suggesting a potential relationship between enhanced NET formation and disease severity (82). Previously linked to the pathogenesis of acute lung 
injury and the onset of ARDS in critically-ill patients (83-86), the authors suggested robust NET formation may propagate the inflammatory storm that appears to precede the onset of severe COVID-19 $(3,82,87)$.

In the context of immunesenescence, both murine and human-based studies have reported a significant age-related reduction in NET formation (88-90). Thus, in contrast to younger adults and those with inflammatory co-morbidities (91-93), we would speculate that in older adults with no preexisting health conditions, any elevation in circulating NET components post SARS-CoV-2 infection would not be a direct consequence of enhanced NET formation. Rather, we suggest that reduced clearance may be responsible. Once dismantled by the endonuclease deoxyribonuclease (DNase)-1, NETs are engulfed by macrophages and degraded in lysosomes, a process facilitated by the opsonisation of NET fragments by the complement protein C1q (94). Whilst no study to our knowledge has investigated the effect of age on DNase-1 activity, there are reports that aging is associated with reduced endocytic and phagocytic activity of macrophages (95-97) as well as reduced lysosomal activity (98). When viewed alongside data from critically-ill patients, in whom DNase activity and uptake of NETs by alveolar macrophages (AM) is significantly reduced $(99,100)$, then older adults with severe COVID-19 are a group that would be predicted to present with a high systemic NET load, a scenario, which in a cohort of patients with severe influenza A infection was associated with the development of multiple organ dysfunction syndrome (101).

NET production, whether assessed by a measurement of circulating markers (e.g., MPO-DNA complexes) or ex vivo generation, is significantly increased in obese subjects and individuals with T2D (91-93), patient groups that are not only at high risk of developing severe COVID-19 $(102,103)$ but who experienced poor outcomes in the $2009 \mathrm{H} 1 \mathrm{~N} 1$ influenza A virus pandemic (104). Whilst multiple factors will underlie the susceptibility of obese and T2D subjects to severe COVID-19, it is intriguing to speculate that remodeling of the innate immune response, in this case a heightened sensitivity for NET generation, could be one such factor, particularly given the cytotoxic and pro-thrombotic nature of NETs $(105,106)$.

NETs may represent a potential therapeutic target for the prevention of poor outcomes such as ARDS in COVID-19. In a recent article, Barnes et al. discussed the therapeutic options that are available to manipulate NET formation and how some of these approaches are already being tested in clinical trials in COVID-19 patients (80). Improvements in clinical indices were reported in a cohort of severe COVID-19 patients that were co-treated with anti-viral agents and dipyridamole, an adenosine-receptor agonist that inhibits NET formation in vitro $(107,108)$. However, whether the observed benefits were related to the modulation of NET production was not addressed (108). Nevertheless, the success that enhancing NET degradation has had in terms of improving clinical markers in patients with virus-associated bronchiolitis $(109,110)$ and reducing both lung injury and mortality rates in murine models of pneumonia (84), should encourage researchers and clinicians to pursue NETs as therapeutic strategies. This is particularly pertinent to older adults, where administration of therapeutic doses of DNase would completely eradicate NETs (94), thereby bypassing the need for macrophage clearance, which is a process that is likely to be impaired with age.

Associated with lymphocytic and neutrophilic infiltrate, postmortem histological examination of lung tissue has shown severe COVID-19 results in extensive diffuse alveolar damage (81). In response to a panel of inflammatory mediators, which included IL-8, C5a, leukotriene B4 and sputum, we have shown aging is associated with impaired migratory accuracy of neutrophils (111). This defect, which was detected in individuals aged $\geq 60$ years, was accompanied by enhanced degranulation and neutrophil proteinase activity, leading us to propose that aging is associated with an increase in neutrophil-mediated bystander tissue damage (111). Interestingly, a similar situation may be observed in T2D patients, whose neutrophils also exhibit impaired migration in vitro $(112,113)$. Furthermore, compared to HCs, circulating levels of the protease inhibitor alpha-1 antitrypsin are significantly lower in T2D subjects (114). Thus, in the context of SARS-CoV-2, we suggest that the meandering neutrophils of both older adults and T2D patients would, via excessive proteinase release, promote more widespread tissue damage and increased systemic inflammation.

\section{Monocytes and Macrophages}

Accompanied by an emergence into circulation of large atypical vacuolated monocytes (115), SARS-CoV-2 infection is associated with alterations in the composition of the peripheral monocyte pool. For example, whereas frequencies of $\mathrm{CD} 14^{++} \mathrm{CD} 16^{-}$ classical monocytes have been reported to be significantly reduced in COVID-19 patients when compared to HCs (115), the proportions of intermediate $\left(\mathrm{CD} 14^{++} 16^{+}\right)$and non-classical $\left(\mathrm{CD} 14^{+} 16^{++}\right)$monocytes are significantly increased $(115,116)$, with analysis also revealing the percentage of intermediate $\mathrm{CD} 14^{++} 16^{+}$monocytes to be significantly higher in patients requiring intensive care unit (ICU) treatment when compared to those with milder disease (116).

Moreover, single cell analysis of PBMCs has reported the presence of a monocyte subset unique to severe COVID-19 patients that is enriched in genes encoding a range of cytokine storm related cytokines such as IL-1 $\beta$, IL-6, and TNF- $\alpha$ (117). Phenotypically, mirroring the immunological changes that occur during sepsis, monocytes from COVID-19 patients exhibit significantly reduced surface expression of the antigen presenting molecule HLA-DR (118). Ex vivo examination of intracellular cytokine levels has revealed an increased frequency of GM-CSF ${ }^{+}$ and IL- $6^{+}$monocytes in both ICU and non-ICU COVID-19 patients, with the percentage of IL- $6^{+}$monocytes correlating with disease severity (116). Similarly, a greater proportion of $\mathrm{CD} 14^{++} \mathrm{CD}^{-} 6^{-} \mathrm{IL} \beta^{+}$monocytes were detected in COVID19 patients by RNA sequencing, which found expression in $\mathrm{CD} 14^{++}$monocytes of pro and anti-inflammatory genes were up and down-regulated, respectively when compared to HCs (68). Whilst more studies are required, emerging data implies a role for IL-6 in driving the SARS-CoV-2-mediated remodeling of the monocyte pool $(117,118)$, with one group demonstrating a significant reduction in the expression of genes 
involved in "leukocyte chemotaxis" and the "acute inflammatory response" in monocytes obtained from COVID-19 patients following treatment with the IL-6 receptor monoclonal antibody Tocilizumab (117).

Physiological aging and obesity are associated with remodeling of the circulating monocyte pool, with older adults and obese subjects exhibiting elevated frequencies of intermediate and non-classical monocytes when compared to younger adults and lean subjects, respectively (119-126). Interestingly, Ong et al. have recently assigned a senescentlike pro-inflammatory phenotype to both non-classical and intermediate monocytes (123). Associated with high expression of the phosphorylated p65 subunit of NK- $\kappa \beta$, both monocyte subsets secreted, in the absence of ex vivo stimulation, an array of pro-inflammatory cytokines and chemokines, which included TNF- $\alpha$, IL-6, and CCL4 (123). Importantly, this basal increase in monocyte activity was associated with significantly elevated plasma levels of IL-6 and TNF- $\alpha$ (123). Thus, in the absence of infection, obese and older adults exhibit a state of heightened peripheral inflammation upon which the abovementioned SARS-CoV-2-mediated changes in monocyte biology would be super-imposed. When combined with the maintained $(42,43,46,47,62)$ or increased (63) generation of pro-inflammatory cytokines by RNA-stimulated monocytes of older adults and obese subjects respectively, we speculate that this high level of basal inflammation would predispose these groups to hyper-inflammation that would hasten the onset of severe COVID-19.

Single cell RNA sequencing (scRNA-seq) of bronchoalveolar lavage fluid (BALF) has revealed the composition of macrophages within the lungs of COVID-19 patients differs based on disease severity. Categorizing macrophages as monocyte-derived, profibrotic or alveolar, Liao et al. found BALF obtained from patients with severe disease was dominated by monocyte-derived and pro-fibrotic macrophages, with the former subset expressing a strong pro-inflammatory gene signature (127). Offering potential insights into the secondary complications that may develop in severe COVID-19 patients as a consequence of this remodeling of lung-resident macrophages, two studies have implicated monocyte-derived AMs in the development of post-injury lung fibrosis and viral-induced pneumonia $(128,129)$. In the context of immunesenescence, it has been proposed that as a consequence of life-long exposure to environmental challenges, monocyte recruitment to the lung increases with age, such that over time, monocyte-derived macrophages become the predominant subset within the lungs (130). If correct, then a more robust pulmonary inflammatory response to SARS-CoV-2 in older adults may increase their susceptibility to developing severe COVID-19.

\section{Natural Killer Cells}

Natural killer (NK) cells are innate immune cells that play a major role in the early recognition and elimination of virally-infected cells. In a murine model of severe SARS-CoV-1 pulmonary infection, Glass et al. demonstrated viral clearance in the absence of NK cells (131), a finding that suggests these innate lymphocytes are not required for host protection against coronaviruses. However, the significant number of studies that have demonstrated marked alterations in the composition and function of the circulating NK cell pool of COVID-19 patients (19) makes a discussion of the NK cell response to SARS-CoV-2, particularly in the context of immunesenescence, necessary.

COVID-19 patients with mild-to-moderate disease present with significantly reduced circulating numbers of total NK cells, driven by a reduction in both $\mathrm{CD} 56^{\mathrm{DIM}} 16^{+}$and $\mathrm{CD} 56^{\mathrm{BRIGHT}}$ NK cell subsets (40, 41, 79, 118, 132-134). Accompanying these numerical changes are significant alterations in NK cell phenotype, with scRNA-seq and flow cytometric analyses revealing the peripheral NK pool of COVID-19 patients is dominated by immature, highly activated and functionally compromised cells $(40,41,134)$. Focussing on the latter, increased frequencies of NK cells expressing the inhibitory receptors TIM3 and NKG2A have been detected in patients with mild/moderate and severe COVID-19 $(40,134)$ with the increase in NKG2A expression potentially reflecting the stimulation of NK cells by pro-inflammatory cytokines (135). Upon recognition of its ligand HLA-E, signaling through NKG2A inhibits NK cell cytotoxicity (NKCC) $(136,137)$. Thus, one would predict that NK cells isolated from COVID-19 patients would exhibit reduced functional responses. Indeed, albeit to a non-viral stimulus, Zheng and colleagues found the frequencies of $\mathrm{CD} 107 \mathrm{a}^{+}, \mathrm{IFN} \gamma^{+}$, $\mathrm{TNF}^{+}$, and IL-2 ${ }^{+}$NK cells in PBMC samples acquired from COVID-19 patients were significantly lower following PMA and ionomycin challenge when compared to HCs (134). As blood samples were acquired at the time of hospital admission, these results imply an immediate breakdown of NK-mediated anti-viral immunity (134). Interestingly, when patients were reanalysed following anti-viral therapy, a marked reduction in the percentage of $\mathrm{NKG}_{2} \mathrm{~A}^{+} \mathrm{NK}$ cells was noted, leading to the suggestion that downregulation of NKG2A may correlate with disease control (134).

A prominent feature of $\mathrm{NK}$ cell immunesenescence is reduced NKCC, a defect we have previously attributed to impaired polarization of the pore forming protein perforin to the immunological synapse (138). Accompanying this decline in lytic activity is an age-related reduction in cytokine and chemokine production (139-141). NK cell function is regulated by the balance of signals transmitted through surface expressed activatory and inhibitory receptors (142). As discussed by others (19), it is currently unknown as to which ligands for activatory receptors are expressed on the surface of SARS CoV-2 infected cells. Possible candidates are stress-inducible ligands, which are recognized by the activatory receptors NKG2D, NKp30, and NKp46. Whilst age has no effect upon the expression of NKG2D $(138,143)$, a number of studies have described an age-associated decline in the frequency of $\mathrm{NKp} 30^{+}$and $\mathrm{NKp} 46^{+} \mathrm{NK}$ cells $(138,144,145)$. Thus, in the older adult with severe COVID-19, superimposed on a baseline reduction in NKCC and activatory receptor expression would be a SARS-CoV-2 driven induction of functional exhaustion via the up-regulation of NKG2A (134). Moreover, with in vitro studies having shown that exposure to IL- 6 and TNF- $\alpha$, two cytokines whose circulating levels are elevated in COVID-19 patients $(3,77,146)$ impairs NKCC and reduces perforin, NKp30 and NKp46 expression (147-149), then the SARS-CoV-2-induced cytokine storm would exacerbate the 
abovementioned functional and phenotypical features of NK cell immunesenescence, which would be predicted to further reduce NK cell anti-viral activity.

Recent studies in the field of cancer immunotherapy have shown that manipulation of NKG2A signaling can restore NKCC and promote anti-tumor immunity $(136,150,151)$. Based on its success, Yaqinuddin and colleagues have proposed mirroring this therapeutic approach for the treatment of COVID-19 patients, where administration of the humanized anti-NKG2A antibody Monalizumab would rejuvenate the anti-viral immune response of COVID-19 patients by counteracting the NKG2A-driven inhibition of NKCC (152). However, for older adults with severe COVID-19, any therapeutic value of this approach may be offset by the age-related impairments in perforin polarization, NKCC and the reduced expression of NK cell activating receptors.

\section{T Cell Responses}

Lymphopenia is a common hematological observation in patients infected with SARS-CoV-2. $\mathrm{CD}^{+}, \mathrm{CD}^{+}$, and $\mathrm{CD}^{+}{ }^{+} \mathrm{T}$ cell counts are significantly lower in patients with severe COVID19 when compared to those with mild disease (57, 60, 133, $134,153)$, with numbers increasing significantly in subjects who respond clinically to anti-viral treatment (133). Elevated circulating concentrations of pro-inflammatory cytokines (133, $154)$, induction of apoptosis (40) and pulmonary infiltration $(5,127)$ are some of the mechanisms that have been proposed to underlie SARS-CoV-2-induced lymphopenia. Indicative of in vivo activation, increased proportions of $\mathrm{CD}^{+}$and $\mathrm{CD}^{+} \mathrm{T}$ cells expressing CD69, CD38, CD44, or HLA-DR have been reported in COVID-19 patients $(5,116,155-158)$ as has the

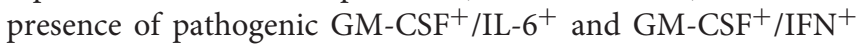
$\mathrm{CD}^{+} \mathrm{T}$ cells, with those experiencing severe disease presenting with significantly increased frequencies when compared to those with mild COVID-19 (116). Pointing toward a state of functional exhaustion or senescence, markedly higher percentages of CD4 ${ }^{+}$ or $\mathrm{CD}^{+} \mathrm{T}$ cells expressing a variety of molecules such as NKG2A, PD-1, TIGIT, TIM-3 and CD57 have been detected in SARS-CoV-2-infected patients $(116,134,154,159)$, with their presence coinciding with significantly reduced intracellular cytokine generation upon ex vivo stimulation $(134,158)$.

Characterized by the gradual replacement of functional epithelial cells with fat and fibrous tissue (160), thymic involution is a defining feature of $\mathrm{T}$ cell immunesenescence, which results in a decline in the production of naïve T lymphocytes (161). This reduction in thymic output is offset by the homeostatic proliferation of pre-existing naïve and memory $\mathrm{T}$ cells, a scenario that results in a contraction in the diversity of the circulating $\mathrm{T}$ cell receptor (TCR) repertoire of older adults (162). As well as aging, obesity is associated with reduced thymic function. Yang and co-workers found the generation of naïve $\mathrm{T}$ cells was significantly lower in obese younger adults when compared to age-matched lean controls (163). As a broad TCR repertoire is crucial for the detection of novel pathogens, the reduced diversity within the $\mathrm{T}$ cell pool of older adults and obese subjects may contribute to their increased susceptibility to SARS-CoV2 infection and put them at risk of eliciting a blunted immune response to any future COVID-19 vaccine.
Owing to impaired metabolism, shortened telomeres and aberrant intracellular signaling $(33,164,165)$, reduced proliferation, cytokine production, cytotoxicity and migration are examples of some of the functional impairments that have been reported for $\mathrm{T}$ cells isolated from older adults and those with inflammatory co-morbidities $(33,166,167)$. The peripheral $\mathrm{T}$ cell pools of these adults are enriched with functionally exhausted $\left(\right.$ TIGIT $^{+}, \mathrm{PD}^{+}{ }^{+}$), highly activated (TIGIT $^{+}$HLA- $^{-}$ $\left.\mathrm{DR}^{+} \mathrm{CD}^{+} 8^{+}\right)$, senescent $\left(\mathrm{CD} 28^{-} 57^{+}, \mathrm{CCR}^{-} 45 \mathrm{RA}^{+}\right)$and terminally differentiated $\left(\mathrm{CD} 27^{-} 28^{-}\right) \mathrm{CD}^{+}$or $\mathrm{CD}^{+} \mathrm{T}$ cells $(33,168-170)$. The most profound changes are witnessed within the $\mathrm{CD}^{+} \mathrm{T}$ cell subset, with the accumulation of $\mathrm{CD}^{+} 28^{-}$ $\mathrm{T}$ cells of particular significance (171). Saurwein-Teissl et al. found an expansion of $\mathrm{CD} 8^{+} 28^{-} \mathrm{T}$ cells was associated with reduced antibody responses in older adults following influenza vaccination (172). The efficiency of $\mathrm{T}$ cell responses are also hampered by age-associated alterations in the expression of co-stimulatory molecules on the surface of antigen presenting cells. Relevant to SARS-CoV-2, monocytes isolated from older adults have been shown to exhibit reduced expression of CD80 and CD86 following ligation of the RNA-sensing PRRs TLR7/8 (173). In subsequent vaccination studies, it was shown that expression of these co-stimulatory molecules was positively associated with antibody responses (173).

Based on scRNA-seq data that has shown the presence of highly expanded and functionally-competent $\mathrm{CD}^{+} \mathrm{T}$ cells in the BALF of mild COVID-19 patients, it has been suggested that a robust adaptive immune response is critical to controlling SARS-CoV-2 infection (127). If correct, then combined with the aforementioned remodeled $\mathrm{T}$ cell pool of older adults and individuals with inflammatory co-morbidities, the SARS-CoV-2 driven induction of lymphocyte exhaustion $(116,134,154,159)$ would hamper both the initiation and maintenance of such a response. Furthermore, due to the reduced vaccine efficacy that occurs as a consequence of both innate and adaptive immune dysfunction, alternative therapeutic strategies such as administration of the immunomodulatory drugs metformin and pioglitazone, have been proposed to protect these high risk groups against severe COVID-19 (174).

\section{B Cells}

Marked alterations have been described in the composition of the circulating B cell pool of SARS-CoV-2 infected patients. Relative to $\mathrm{HC}$ 's, significantly reduced frequencies of naïve $\operatorname{IgM}^{+} \mathrm{CD} 27^{-}$, memory $\mathrm{CD} 21^{+} 27^{+}$and $\mathrm{CD}^{+} \mathrm{B}$ cells have been reported $(175,176)$, and are accompanied by a concurrent elevation in the proportion of $\mathrm{CD} 38^{+} 27^{+}$plasmablasts (175-177). When analyzed by disease severity, significant alterations in plasmablast and memory $\mathrm{CD} 21^{+} 27^{+} \mathrm{B}$ cell frequencies were observed only in patients with severe COVID-19 disease, with the proportions of both subsets returning to levels comparable to those of HCs upon recovery $(175,176)$. Demonstrating a rapid and robust $B$ cell response to SARS-CoV-2 infection, elevated circulating levels of virus specific IgM, IgG, and IgA antibodies have been detected, with this seroconversion evident within 7-14 days post-symptom onset $(19,68,175,176,178)$. Interestingly, in a small pilot study of five critically-ill COVID-19 patients, transfusion of convalescent 
plasma containing neutralizing SARS-CoV-2 specific antibodies was shown to improve clinical status (179). In terms of the longevity of the antibody response, SARS-CoV-2 specific IgG antibodies have been detected in serum samples acquired from COVID-19 patients 7 weeks post-infection (180). However, due to the infancy of the current pandemic, it is currently unknown as to whether this initial antibody response and generation of memory B cells will protect against re-infection. That said, data from previous coronavirus outbreaks, in which a progressive decline in both SARS-CoV-1 specific IgG memory B cells and IgG antibodies were reported $(181,182)$, suggests that SARS-CoV-2 antibody responses will wane over time.

Attributed to a range of factors such as changes in the bone marrow microenvironment and skewing of haematopoietic stem cell differentiation toward the myeloid lineage, murine-based studies have shown aging is associated with a reduction in mature B cell production (183). In line with this observation, human aging is accompanied by a reduction in the size of the peripheral $B$ cell pool, with both the frequency and absolute numbers of CD19+ B cells significantly lower in older adults (183-185). However, whether human aging is associated with changes in the composition of the peripheral B cell pool is unclear. For example, whilst some groups have reported an age-related increase in the percentage or number of circulating $\mathrm{CD} 27^{+}$memory B cells (185), others have demonstrated an age-associated decline in this subset $(183,184)$. Similarly, the frequency of IgM memory B cells have been reported to be either decreased (186) or unchanged with age (184).

Results of human and animal-based studies have revealed that aging is associated with reduced B cell proliferation and differentiation into plasma cells, which secrete antibodies that are weaker and of lower affinity when compared to those produced by plasma cells of younger subjects (186-189). Critical steps in a humoral immune response are class switch recombination (CSR) and somatic hypermutation (SHM). Taking place in germinal centers, these two processes are responsible for the generation of isotype-switched high-affinity antibodies. Essential for both CSR and SHM is activation-induced cytidine deaminase (AID), a DNA-editing enzyme, whose expression is regulated by the transcription factor E47. Culminating in defective class switching, the expression of both AID and E47 has been shown to be significantly lower in B cells from aged mice and humans $(184,190,191)$. Alongside these intrinsic defects, B-cell extrinsic factors also contribute to the age-related impairment in humoral immunity. For example, attributed to reduced surface expression of Fc receptors, follicular dendritic cells of aged mice exhibit reduced antigen trapping and presentation (192), whilst the agerelated decline in CD40L expression on the surface of activated $\mathrm{CD}^{+} \mathrm{T}$ cells would reduce the delivery of co-stimulatory signals to antigen-expressing B cells (193).

$B$ cell immunesenescence is considered a major underlying factor in the reduced efficacy of vaccination in older adults. Characterized by decreased antibody concentrations, delayed peak antibody titres and lower seroprotection (194-196), the humoral response to a range of vaccinations such as influenza (197) and Hepatitis A (196) is significantly reduced in older adults. Furthermore, accompanying this impairment in initial antibody responses is an age-associated decline in antibody persistence, with one study reporting non-protective antibody titres to be present in older adults 6-10 years following vaccination with tetanus toxoid (198). In the context of COVID19 , these studies highlight the need for research groups involved in designing a SARS-CoV-2 vaccine to consider the impact that age will have on its efficacy, and whether one vaccine will confer protection amongst all groups of society. With this in mind, it may be that a vaccination strategy specific for older adults is required. This could involve the co-administration of an adjuvant or delivery of a booster vaccine, two strategies that have previously proven successful in augmenting antibody titres and conferring seroprotection in aged rhesus monkeys and humans $(199,200)$.

\section{Inflammaging}

Physiological aging is accompanied by a sub-clinical chronic low-grade state of systemic inflammation, inflammaging. This phenomenon is characterized by elevated serum levels of acute phase proteins (e.g., C-reactive protein) and pro-inflammatory cytokines (e.g., TNF- $\alpha$, IL-6, and IL-8) (201). Previous papers that have discussed COVID-19 in the context of aging and immunesenescence have speculated that inflammaging would predispose the older adult to severe infection by fuelling an exaggerated pro-inflammatory response to SARS-CoV-2 (202, 203). However, based on emerging data that suggests excessive pro-inflammatory responses in older adults negatively regulates their immune responses $(204,205)$, we propose the following alternative hypothesis: inflammaging predisposes older adults to severe COVID-19 by suppressing the immune response to SARS$\mathrm{CoV}$-2. Whilst in vitro and in vivo studies have demonstrated that exposure to pro-inflammatory cytokines can modulate the phenotype and/or function of innate and adaptive immune cells (147-149, 206), it is the work of Akbar et al. that have specifically linked hyper-inflammation to impaired antigen specific immune responses during aging. Using a human experimental system that investigates antigen-specific immunity in vivo, the group has consistently demonstrated an age-related impairment in the delayed type hypersensitivity (DTH) response to varicella zoster virus (VSV) antigen (204, 205, 207). Attributed to aberrant activation of P38 MAPK signaling, the decreased VZV antigen responsiveness of older adults is associated with an accumulation of $\mathrm{CCR}^{+}$monocytes that inhibit $\mathrm{T}$ cell proliferation via the production of prostaglandin E2 $\left(\mathrm{PGE}_{2}\right)(204,205)$.

In terms of COVID-19, it is interesting that the aging lung is characterized by a state of heightened basal inflammation, with levels of IL-6, amongst other cytokines, significantly higher in the BALF of healthy older adults when compared to their younger counterparts (208-210). It has been suggested that a life-long accumulation of senescent cells may be responsible for this age-associated increase in pulmonary inflammation (210). Whilst data from murine models support this assumption (211), it is currently unknown in humans as to whether aging is associated with an increased senescent cell burden in the lungs. However, it is interesting that metatranscriptomic sequencing of BALF from COVID-19 patients aged 40-61 years detected an up-regulation of CCL2 (212), a chemokine produced in large 
amounts by senescent cells $(213,214)$. Moreover, CCL2 is the chemoattractant for $\mathrm{CD} 14^{++} \mathrm{CCR} 2^{+}$classical and intermediate monocytes, which in the abovementioned VZV models were more abundant at sites of antigenic challenge in older adults and negatively regulated the adaptive immune response (204). Thus, in response to SARS-CoV-2, the pulmonary immune response of older adults may share features reminiscent of the impaired cutaneous immune response described in DTH models, in that, via the CCL2-mediated recruitment of $\mathrm{PGE}_{2}$-secreting monocytes, a hyper-inflammatory response would impede $\mathrm{T}$ cell function.

Residing in a state of permanent cell cycle arrest, yet remaining metabolically active, senescent cells are a rich source of pro-inflammatory cytokines, chemokines, growth factors and proteases (215). Due to this inflammatory profile, termed the senescent associated secretory phenotype (SASP), and their presence in various tissues of older adults and T2D patients (216-218), senescent cell accumulation is considered to be one factor underlying the heightened systemic inflammatory status of these individuals. Recently, it was demonstrated that certain viruses such as influenza virus exhibit enhanced replication efficiency in senescent cells (219). In terms of coronavirus, entry of SARS-CoV-1 into host cells has been shown to be dependent upon surface expression of vimentin, a filament protein that interacts directly with the spike protein of SARS-CoV-1 (220). Since vimentin was recently found to be expressed on the surface of senescent lung fibroblasts (221), and the fact that SARS-CoV-1 and SARS-CoV-2 utilize the same mechanism of attachment to host cells, a number of groups have proposed increased SARS-CoV-2 replication would occur in individuals with a high senescent cell burden (222-224). Thus, an increased presence of senescent cells may predispose to the development of severe COVID-19 via two mechanisms: (1) reduced immune cell clearance by contributing to the aforementioned inflammationinduced suppression of innate and adaptive immunity (204, 205, 225 ) and (3) increasing viral load by acting as a site of enhanced SARS-CoV-2 replication. Interestingly, a number of clinical trials assessing the therapeutic benefit of drugs that directly eliminate senescent cells or suppress their SASP are already underway in patients with COVID-19 $(223,226)$. Results of such studies will help researchers address whether a high senescent cell burden is indeed a risk factor for the development of severe COVID-19.

Belonging to one of two distinct subsets, namely monocytic or granulocytic, myeloid-derived suppressor cells (MDSC's) are a heterogeneous collection of immature cells. Via a range of mechanisms, which include the generation of ROS and nitric oxide, arginine metabolism, induction of $\mathrm{T}$ regulatory cells and the production of anti-inflammatory cytokines, MDSC's are potent immune suppressors, inhibiting the proliferation and activation of innate (NK cells, DC's and macrophages) and adaptive ( $\mathrm{T}$ and $\mathrm{B}$ cells) immune cells $(227,228)$. Whilst the presence of MDSC's during acute inflammatory responses is seen as beneficial (due to their involvement in the resolution of inflammation), in the setting of chronic inflammation, where MDSC's persist, their suppressive activity is considered detrimental to the host (229). Thus, the elevated frequency of MDSC's reported in older adults, obese subjects and T2D patients (230-232) has been proposed as a potential mechanistic explanation for the increased susceptibility to infection and poor vaccination responses elicited by these individuals $(233,234)$. Given that such inflammatory mediators as PGE 2 , IL-6, TNF- $\alpha$, and GM-CSF promote the expansion and activation of MDSC's (227), the hyperactive immune response and cytokine storm described in SARS-CoV-2-infected patients has resulted in a handful of studies investigating whether MDSC's may contribute to the pathogenesis of COVID-19.

Relative to HC's, significantly elevated frequencies of MDSC's (235) and granulocytic-MDSC's (G-MDSCs) (236) have been detected in peripheral blood samples obtained from mild and severe COVID-19 patients. Suggestive of driving reduced anti-viral immune responses, significant negative associations were reported between MDSC frequency and the percentage of perforin ${ }^{+} \mathrm{CD}^{+} \mathrm{T}$ cells and perforin ${ }^{+} \mathrm{NK}$ cells (235), whilst in ex vivo cultures, depletion of G-MDSC's from PBMC samples of severe COVID-19 patients restored the proliferative capacity and cytokine production of $\mathrm{T}$ cells (236). In terms of disease severity, MDSC frequency has been reported to be significantly higher in patients with severe COVID-19 when compared to subjects with mild disease (236), whilst single cell transcriptomics has revealed the presence of immature $\mathrm{CD}_{14}{ }^{+} \mathrm{MPO}^{+} \mathrm{Ki}_{6}{ }^{+} \mathrm{HLA}-\mathrm{DR}{ }^{\mathrm{lo}}$ suppressive monocytes and immature $\mathrm{ARG}^{+}{ }^{+} \mathrm{CD} 101^{+} \mathrm{S} 100 \mathrm{~A} 8 / \mathrm{A} 9^{+}$neutrophils only in patients with severe disease (237). Furthermore, there is evidence to suggest that MDSC's persist in severe patients, with one study reporting G-MDSC's comprised $>30 \%$ of total PBMC's in samples acquired from 3 severe COVID-19 patients at day 18 post-hospital admission (236). Thus, it has been hypothesized that a SARS-CoV-2-induced expansion of MDSC's may promote immune paralysis and that current therapeutic approaches targeting the cytokine storm may have the additional benefit of augmenting anti-viral immune responses by reducing MDSC proliferation and activation (235).

\section{Age-Associated Changes in Pulmonary Immune Responses}

Thus, far, our discussion of how immunesenescence may predispose to severe COVID-19 has focussed on the changes that occur in the composition, phenotype and/or function of circulating immune cells. As a respiratory tract infection, it is important to discuss the pulmonary immune response.

As the resident immune cell of the lungs, studies that have examined the effect of age on the pulmonary immune response have focussed predominantly upon the AM. Gene profiling of resting AMs has shown aging induces wide-spread transcriptional changes in aged mice (97), with up-regulation of inflammatory pathways related to oxidative burst and IL-8 supporting the notion that aging is associated with heightened basal inflammation within the lung (97). Intertwined with this pulmonary inflammaging is reduced AM function $(95,97,238)$, with the work of Hinojosa et al. suggesting the elevation in basal inflammation is linked to impaired cytokine production via an up-regulation in AMs of A20, a negative regulator of NK-к $\beta$ and MAPKs (239). As both these signaling elements 
function downstream of the RNA sensing PRRs TLR7/8 and RIG-1, pro-inflammatory cytokine production by AMs following SARS-CoV-2 stimulation may be reduced with age. This theory is supported by the significantly reduced production of IL-6 by AMs from aged mice following ex vivo stimulation with the TLR7/8 agonist R848, an impairment that was reported alongside a down-regulation of TLR8 gene expression and a reduced induction of genes related to IL-6 signaling in lung tissue from aged mice following viral infection (240). Other age-related defects reported in the pulmonary immune response include reduced NKCC (241), impaired migration of pulmonary DCs to draining lymph nodes (DLNs) (242), diminished virusspecific $\mathrm{CD}^{+} \mathrm{T}$ cell responses (242-245) and delayed immune cell infiltration $(74,245)$. Results of adoptive transfer experiments point toward an immune suppressive environment rather than cell-intrinsic defects as the cause of some of the abovementioned functional impairments, with one study attributing the ageassociated impairment in pulmonary DC and T cell responses to elevated levels of the immune suppressive eicosanoid $\mathrm{PGD}_{2}$ in the lungs of aged mice $(97,242)$.

Insights into how aging may specifically affect the pulmonary immune response to SARS-CoV-2 are offered by the results of murine and non-human primate models of SARS-CoV-1 infection (242, 246-251). Replicating the situation in humans, disease severity and lethality in these models are higher in aged animals when compared to their younger counterparts (242, 247249), and interestingly, the immune dysregulation that occurs in aged mice infected with SARS-CoV-1 is greater than that detected during influenza A virus infection (242). Features of the pulmonary immune response of aged animals to SARS-CoV-1 include: reduced DC migration to DLNs (242), impaired CD8 ${ }^{+}$ viral-specific $\mathrm{T}$ cell responses (242), decreased macrophage and DC activation (247), reduced T cell proliferation (247) and enhanced pro-inflammatory cytokine responses (246, 248, 249). Those studies that have reported an age-related increase in viral-induced inflammation have shown this exaggerated response is associated with significant lung damage, leading to the suggestion that a pathological immune response may contribute to the increased morbidity and mortality rates in older adults following coronavirus infection (246). Using two distinct approaches, namely antagonism of $\mathrm{PGD}_{2}$ signaling (242) or prophylactic treatment with the TLR3 agonist poly IC (251), it is possible to enhance the pulmonary immune response of older animals to SARS-CoV-1 and increase host survival $(242,251)$. Demonstrating reversal of immunesenescence, these therapeutic strategies have been proposed as a potential means of improving clinical outcome in older adults at high risk of severe respiratory infections $(242,251)$.

\section{RESOLUTION OF INFLAMMATION}

A co-ordinated multi-step program that involves the clearance of apoptosed neutrophils by macrophages (efferocytosis) and the generation of specialized pro-resolving lipid mediators (SPMs), the resolution of inflammatory responses is an active process that protects against unwarranted tissue damage (252). Whilst we await data relating specifically to features of the resolution phase in SARS-CoV-2-infected patients, a series of murine and humanbased studies have shown aging $(97,225,253)$, obesity $(254,255)$ and T2D $(254,256)$ are all associated with delayed resolution of inflammatory responses.

Attributed to a 38 MAPK driven reduction in the expression of T-cell immunoglobulin mucin protein 4 (TIM-4), a receptor expressed by macrophages that recognizes phosphatidylserine on the surface of apoptosed neutrophils, De Maeyer and colleagues recently demonstrated an age-associated impairment in efferocytosis (225). In a human dermal model of acute sterile inflammation, this defect in efferocytosis resulted in the accumulation of annexin $\mathrm{V}^{+}$neutrophils and delayed resolution (225). Mirroring these observations, reduced clearance of apoptosed cells by macrophages has been reported in the experimental settings of obesity $(97,254,257)$ and diabetes $(254$, 256, 258), with decreased PI3-K signaling (257) and elevated $\mathrm{PGE}_{2}$ levels in inflammatory exudate (254) identified as potential underlying causes. In addition to defective efferocytosis, reduced concentrations of SPMs have been measured at sites of acute inflammation in murine models of aging (253) and diabetes (256). Augmenting SPM levels via exogenous administration shortened resolution time in vivo, with this improvement linked to increased efferocytosis and the reprogramming of monocytes to a pro-resolving phenotype (253). Based on these data, we propose that, via their delayed induction of resolution programs, groups at high risk of COVID-19 would experience prolonged inflammatory responses following SARS-CoV-2 infection. By exacerbating their pre-existing heightened pro-inflammatory status, this impairment in resolution would promote further immune dysregulation and bystander tissue damage that would result in delayed viral clearance and an extended time to recovery. On this note, coinciding with impaired efferocytosis in vitro, Wong et al. observed greater neutrophil retention in the lungs and higher myeloperoxidase levels in the BALF of aged mice following influenza A virus infection (97). Interestingly, adoptive transfer of AMs from young mice into aged mice significantly reduced the degree of lung damage measured 3 days post influenza A virus challenge (97).

Associated with pathogen dissemination, impaired lung function and increased mortality $(259,260)$, down-regulation of ALOX5 (the gene responsible for the synthesis of the SPM lipoxin) and reduced production of the SPM protectin D1 (PD1) have been reported in murine models of severe influenza infection. Based in part on the fact that in these models administration of PD1 improved survival rates and pulmonary function (260), SPM treatment has been proposed as a therapy by which to promote the resolution of lung inflammation and reduce tissue damage in COVID-19 patients (261). Importantly, treatment regimens that include exogenous application of SPMs and inhibition of P38 MAPK have been shown in human and animal models to overcome the delay in inflammatory resolution that occurs as a consequence of aging and the presence of comorbidities $(225,253,256)$. Thus, it appears that resolution of inflammation can be manipulated in groups at high risk of severe COVID-19. However, as histological examination of lung tissue obtained from a SARS-CoV-1 infected patient found 
increased expression of plasminogen activator inhibitor-1 (262), a negative regulator of efferocytosis (263), there may be obstacles beyond impaired SPM generation that need to be overcome in order to successfully promote the resolution of coronavirusinduced inflammatory responses in older adults and those with inflammatory co-morbidities.

\section{FUTURE DIRECTIONS}

\section{Immunesenescence and the Development of a COVID-19 Vaccine}

A recent report by the World Health Organization provided information on the 26 candidate COVID-19 vaccines that are currently undergoing clinical testing and details of a further 139 that are in preclinical evaluation (264). The speed of COVID19 vaccine research was highlighted by the fact that within 68 days of being declared a pandemic, results of the first animal and human based studies to test potential vaccines were published (265). Across rodents and non-human primates, the efficacy of an adenovirus-vectored vaccine encoding the spike protein of SARS-CoV-2 (266), a purified inactivated virus vaccine (267) and a series of DNA vaccines expressing different forms of the spike protein (268) have been tested, with preliminary results demonstrating the generation of robust humoral and cell-mediated responses that significantly reduce viral load and prevent the development of pneumonia $(266,267)$. Moderna Therapeutics recently announced the results of their phase 1 human trial of a potential COVID-19 vaccine (269). Using an mRNA vaccine that encodes for a pre-fusion stabilized form of the SARS-CoV-2 spike protein, the company reported seroconversion following a single dose in all 45 participants, with those who received two doses generating antibody levels akin to those measured in patients that have recovered from COVID-19 (269). However, it will be important to consider the impact of age and co-morbidities on the efficacy of any potential vaccine.

To date, a number of animal-based studies have investigated the effect of age on the efficacy of SARS-CoV-1 vaccines (270272). In response to infection with homologous or heterologous viral strains, Bolles et al. found that aged mice vaccinated with an adjuvanted-double-inactivated whole SARS-CoV-1 virus were not completely protected against virus-induced mortality and exhibited both increased morbidity and pulmonary viral load when compared to young mice (270). Underlying this impairment in vaccine efficacy was a significant age-associated reduction in serum neutralizing antibody titres (270). However, in a related study, Sheahan et al. used a virus replicon particle vaccine platform that specifically targeted DCs, and showed that this strategy resulted in comparable antigen-specific IgG responses between young and aged mice and protected older mice from SARS-CoV-1-mediated clinical disease (272). Taken together, these data not only demonstrate the importance of testing any potential COVID-19 vaccine in all age groups but highlight how vaccine design will be critical for inducing protective antibody responses in aged hosts. On this note, a number of therapeutic strategies have been proposed and/or trialed in an attempt to combat the reduced efficacy of vaccinations against viral antigens in older adults (273). To date, these have included immunostimulant patches (274), the use of TLR agonists as adjuvants (275), the fusion of viral proteins with TLR agonists (276), high dose vaccination (277-279) and the use of $\mathrm{PGD}_{2}$ antagonists (242).

It is becoming increasingly recognized that obesity is a risk factor for infectious disease and poor vaccination responses (280-283). Data from mice (284-286) and human $(287,288)$ studies have reported reduced influenza vaccine efficacy in obese subjects, which in murine studies was associated with increased lung pathology, higher viral titres and greater mortality rates upon secondary infection $(284,285)$. Studies are underway to investigate methods of counteracting the negative effects of obesity on vaccine responses. Of note, whilst the use of adjuvants and/or high dose vaccination have been shown to increase neutralizing antibody titres in obese mice, the levels generated as well as the breadth and magnitude of the antibody response was significantly lower when compared to lean controls, ultimately resulting in reduced protection upon viral challenge (289). Thus, when viewed alongside the abovementioned agerelated impairment in vaccine efficacy, these results imply that a "one size fits all" policy may not be appropriate for a COVID-19 vaccine, with high risk groups requiring a tailored vaccine designed to overcome the deficits of their remodeled immune systems.

\section{Enhancing Immune Function in Older Adults}

Through pharmacological and non-pharmacological approaches, which include nutritional intervention $(290,291)$ and the administration of protein kinase inhibitors (204, 205, 225, 292, 293), clinical studies in older adults have shown it is possible to reverse immunesenescence.

Associated with reduced circulating frequencies of functionally exhausted $\mathrm{PD}-1$ positive $\mathrm{CD}^{+}$and $\mathrm{CD}^{+} \mathrm{T}$ cells, Mannick et al. demonstrated a significantly enhanced serological response to influenza vaccination in older adults treated with the allosteric mammalian target of rapamycin (mTOR) inhibitor RAD001 prior to antigenic challenge (292). More recently, the same group reported that a combined therapy of RAD001 and BEZ235, a competitive mTOR inhibitor, significantly reduced the annualized rate of respiratory tract infections in adults aged $\geq 65$ years (293). mRNA sequencing analysis of circulating leukocytes revealed this protective effect was accompanied by an up-regulation in genes related to anti-viral type I IFN signaling (293).

Oral administration of the potent and selective P38 MAPK inhibitor losmapimod has been shown to boost cutaneous immune responses in older adults. In a model of DTH, P38 inhibition was found to significantly increase VZV antigen specific immunity (205). Mechanistically, at the site of antigenic challenge, this improved immune response was associated with significantly reduced infiltration of $\mathrm{PGE}_{2}$ producing CCR2 ${ }^{+}$ monocytes and increased $\mathrm{T}$ cell proliferation, whilst systemically, a significant decline in serum CRP levels was reported 
(204, 205). Importantly, losmapimod treatment also augments the resolution response of older adults (225), meaning that the improved immune response that would occur following P38 inhibition would not be offset by bystander tissue damage that would arise from the delay in the resolution of inflammatory responses that accompanies physiological aging (225).

Taken together, these studies demonstrate that it is possible to enhance anti-viral immunity and resolution responses in older adults. In the context of SARS-CoV-2 infection, these treatment regimens could be applied in a prophylactic manner to prevent the spread of COVID-19 and boost immune responses to future vaccines. Having already proven successful in elderly subjects, these therapeutic strategies have an advantage over many other potential treatments whose efficacy would be hampered by the remodeling of the immune system that occurs with age.

\section{CONCLUDING REMARKS}

The similarities that exist between the immune response that precedes or accompanies the onset of severe COVID-19, and the re-modeled immune systems of older adults and those with inflammatory co-morbidities, lend support to the idea that immunesenescence may predispose to COVID-19 infection and disease severity (Figure 1). However, current evidence is at best circumstantial $(202,203)$, with the lack of cross-sectional and prospective studies examining the SARS$\mathrm{CoV}$-2-induced immune response in these high risk groups hindering our ability to address this hypothesis. That said, it appears that such studies are underway (10, 154, 294). For example, in a recent study, Liu et al. divided a cohort of 221 COVID-19 patients into two distinct age groups, and found older adults ( $\geq 60$ years of age) presented with significantly elevated inflammatory indices (10). Furthermore, a study at University College London has acquired pre-infection blood and throat swab samples from people $\geq 70$ years of age who will be assessed weekly for COVID-19 related symptoms (294, 295). Working on a hypothesis that prior exposure to coronaviruses may lead to an exaggerated immune response against SARS-CoV-2, one aim of the study is to determine pre-infection antibody titres against other coronaviruses (295). The results of this study, which also plans to search for



Severe COVID-19 $\downarrow$ Type I IFN production

$\uparrow$ Generation of pro-inflammatory cytokines

$\uparrow$ NET production

$\uparrow$ Frequency of pro-inflammatory monocytes

$\downarrow$ NK cell cytokine production

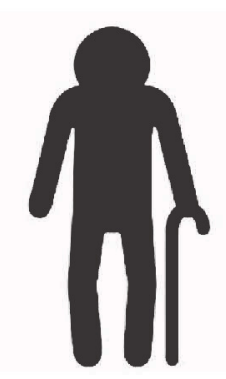

Healthy Older Adults $\downarrow$ Type I IFN production

Chronic low-grade systemic inflammation

$$
\begin{gathered}
\text { T Frequency of } \\
\text { pro-inflammatory } \\
\text { monocytes }
\end{gathered}
$$



\section{Adults with Inflammatory Co-morbidities}

\section{Accumulation of functionally exhausted and senescent $\mathrm{CD} 4^{+}$and $\mathrm{CD}^{+} \mathrm{T}$ cells}
Accumulation of functionally exhausted and senescent $\mathrm{CD4} 4^{+}$and $\mathrm{CD}^{+} \mathrm{T}$ cells

\section{Accumulation of functionally exhausted and senescent $\mathrm{CD4} 4^{+}$and $\mathrm{CD}^{+} \mathrm{T}$ cells}

FIGURE 1 | Immunesenescence: a risk factor for severe COVID-19? Similarities between the immune profile of patients with severe COVID-19, healthy older adults and adults with inflammatory co-morbidities (obesity and type 2 diabetes). IFN, Interferon; NET, Neutrophil extracellular traps; NK, Natural killer. 
biomarkers that are predictive of outcome in those subjects who develop COVID-19 $(294,295)$, will provide a much needed insight into how the immune system of older adults responds to SARS-Cov-2 and whether it is a contributory factor in patient outcome.

\section{AUTHOR CONTRIBUTIONS}

$\mathrm{JH}$ wrote the manuscript. JL critically appraised the manuscript. All authors have seen and approved the final submission.

\section{REFERENCES}

1. Zhu N, Zhang D, Wang W, Li X, Yang B, Song J, et al. A novel coronavirus from patients with pneumonia in China, 2019. N Engl J Med. (2020) 382:72733. doi: 10.1056/NEJMoa2001017

2. World Health Organisation Coronavirus Disease (COVID-19) Situation Report-14. (2020). Available online at: https://www.who.int/docs/defaultsource/coronaviruse/situation-reports/20200616-covid-19-sitrep-148draft.pdf?sfvrsn=9b2015e9_2. (accessed June 17, 2020).

3. Huang C, Wang Y, Li X, Ren L, Zhao J, Hu Y, et al. Clinical features of patients infected with 2019 novel coronavirus in Wuhan, China. Lancet. (2020) 395:497-506. doi: 10.1016/S0140-6736(20)30183-5

4. Wang D, Hu B, Hu C, Zhu F, Liu X, Zhang J, et al. Clinical characteristics of 138 hospitalized patients with 2019 novel coronavirus-infected pneumonia in Wuhan, China. JAMA. (2020) 323:1061-9. doi: 10.1001/jama.2020.1585

5. Xu Z, Shi L, Wang Y, Zhang J, Huang L, Zhang C, et al. Pathological findings of COVID-19 associated with acute respiratory distress syndrome. Lancet Respir Med. (2020) 8:420-2. doi: 10.1016/S2213-2600(20)30076-X

6. Yang X, Yu Y, Xu J, Shu H, Xia J, Liu H, et al. Clinical course and outcomes of critically ill patients with SARS-CoV-2 pneumonia in Wuhan, China: a single-centered, retrospective, observational study. Lancet RespirMed. (2020) 8:475-81. doi: 10.1016/S2213-2600(20)30079-5

7. Garg S, Kim L, Whitaker M, O'Halloran A, Cummings C, Holstein R, et al. Hospitalization rates and characteristics of patients hospitalized with laboratory-confirmed coronavirus disease 2. MMWR Morb Mortal Wkly Rep. (2020) 69:458-64. doi: 10.15585/mmwr.mm6915e3

8. Grasselli G, Zangrillo A, Zanella A, Antonelli M, Cabrini L, Castelli A, et al. Baseline characteristics and outcomes of 1591 patients infected with SARS-CoV-2 admitted to ICUs of the Lombardy Region, Italy. JAMA. (2020) 323:1574-81. doi: 10.1001/jama.2020.5394

9. Cao J, Hu X, Cheng W, Yu L, Tu WJ, Liu Q. Clinical features and short-term outcomes of 18 patients with corona virus disease 2019 in intensive care unit. Intensive Care Med. (2020) 46:851-3. doi: 10.1007/s00134-020-05987-7

10. Liu Y, Mao B, Liang S, Yang JW, Lu HW, Chai YH. Association between ages and clinical characteristics and outcomes of coronavirus disease 2019. Eur Respir J. (2020) 55:2001112. doi: 10.2139/ssrn.3556689

11. Petrilli CM, Jones SA, Yang J, Rajagopalan H, O'Donnell L, Chernyak Y, et al. Factors associated with hospital admission and critical illness among 5279 people with coronavirus disease 2019 in New York City: prospective cohort study. BMJ. (2020) 369:m1966. doi: 10.1136/bmj.m1966

12. Sun K, Chen J, Viboud C. Early epidemiological analysis of the coronavirus disease 2019 outbreak based on crowdsourced data: a population-level observational study. Lancet Digit. Health. (2020) 2:e2018. doi: 10.1016/S2589-7500(20)30026-1

13. Williamson E, Walker AJ, Bhaskaran KJ, Bacon S, Bates C, Morton CE, et al. OpenSAFELY: factors associated with COVID-19-related hospital death in the linked electronic health records of 17 million adult NHS patients. medRxiv [Preprint]. (2020). doi: 10.1101/2020.05.06.20092999

14. Wu C, Chen X, Cai Y, Xia J, Zhou X, Xu S, et al. Risk factors associated with acute respiratory distress syndrome and death in patients with coronavirus disease 2019 Pneumonia in Wuhan, China. JAMA Intern Med. (2020) 180:934-43. doi: 10.1001/jamainternmed.2020.0994

\section{FUNDING}

JH was supported by the National Institute for Health Research (NIHR) Surgical Reconstruction and Microbiology Research Centre (SRMRC) and JL by the NIHR Birmingham Biomedical Research Centre.

\section{ACKNOWLEDGMENTS}

The views expressed are those of the author(s) and not necessarily those of the NIHR or the Department of Health and Social Care.

15. Zhou F, Yu T, Du R, Fan G, Liu Y, Liu Z, et al. Clinical course and risk factors for mortality of adult inpatients with COVID-19 in Wuhan, China: a retrospective cohort study. Lancet. (2020) 395:105462. doi: 10.1016/S0140-6736(20)30566-3

16. Centers for Disease Control Prevention. Provisional COVID-19 Death Counts by Sex, Age and State. (2020). Available online at: https://data.cdc. gov/NCHS/Provisional-COVID-19-Death-Counts-by-Sex-Age-and-S/ 9bhg-hcku (accessed June 17, 2020).

17. Office for National Statistics. Deaths Registered Weekly in England and Wales, Provisional: Week Ending 5 June 2020. (2020). Available online at: https://www.ons.gov.uk/ peoplepopulationandcommunity/birthsdeathsandmarriages/deaths/ bulletins/deathsregisteredweeklyinenglandandwalesprovisional/ weekending29may2020\#deaths-registered-by-age-group (accessed June 17, 2020).

18. Verity R, Okell LC, Dorigatti I, Winskill P, Whittaker C, Imai N, et al. Estimates of the severity of coronavirus disease 2019: a model-based analysis. Lancet Infect Dis. (2020) 20:669-77. doi: 10.1016/S1473-3099(20)30243-7

19. Vabret N, Britton GJ, Gruber C, Hegde S, Kim J, Kuksin M, et al. Immunology of COVID-19: current state of the science. Immunity. (2020) 52:91041. doi: 10.1016/j.immuni.2020.05.002

20. Marston BJ, Plouffe JF, File TM Jr, Hackman BA, Salstrom SJ, Lipman $\mathrm{HB}$, et al. Incidence of community-acquired pneumonia requiring hospitalization. results of a population-based active surveillance study in ohio the community-based pneumonia incidence study group. Arch Intern Med. (1997) 157:1709-18. doi: 10.1001/archinte.1997.00440360129015

21. Molony RD, Malawista A, Montgomery RR. Reduced dynamic range of antiviral innate immune responses in aging. Exp Gerontol. (2018) 107:1305. doi: 10.1016/j.exger.2017.08.019

22. Lord JM. The effect of ageing of the immune system on vaccination responses. Hum Vaccin Immunother. (2013) 9:1364-7. doi: 10.4161/hv. 24696

23. Chen N, Zhou M, Dong X, Qu J, Gong F, Han Y, et al. Epidemiological and clinical characteristics of 99 cases of 2019 novel coronavirus pneumonia in Wuhan, China: a descriptive study. Lancet. (2020) 395:50713. doi: 10.1016/S0140-6736(20)30211-7

24. Khawaja AP, Warwick AN, Hysi PG, Kastner A, Dick A, Khaw PT, et al. Associations with covid-19 hospitalisation amongst 406,793 adults: the UK Biobank prospective cohort study. medRxiv [Preprint]. (2020). doi: 10.1101/2020.05.06.20092957

25. Huang I, Lim MA, Pranata R. Diabetes mellitus is associated with increased mortality and severity of disease in COVID-19 pneumonia - A systematic review, meta-analysis, and meta-regression. Diabetes Metab Syndr. (2020) 14:395-403. doi: 10.1016/j.dsx.2020.04.018

26. Lighter J, Phillips M, Hochman S, Sterling S, Johnson D, Francois F, et al. Obesity in patients younger than 60 years is a risk factor for Covid-19 hospital admission. Clin Infect Dis. (2020) 71:896-7. doi: 10.1093/cid/ciaa415

27. Sattar N, McInnes IB, McMurray JJV. Obesity a risk factor for severe COVID-19 infection: multiple potential mechanisms. Circulation. (2020) 142:4-6. doi: 10.1161/CIRCULATIONAHA.120.047659

28. Simonnet A, Chetboun M, Poissy J, Raverdy V, Noulette J, Duhamel A, et al. High prevalence of obesity in severe acute respiratory syndrome 
coronavirus-2 (SARS-CoV-2) requiring invasive mechanical ventilation. Obesity (Silver Spring). (2020) 28:1195-9. doi: 10.1002/oby.22831

29. Watanabe M, Risi R, Tuccinardi D, Baquero CJ, Manfrini S, Gnessi L. Obesity and SARS-CoV-2: a population to safeguard. Diabetes Metab Res Rev. (2020) e3325. doi: 10.1002/dmrr.3325. [Epub ahead of print].

30. Bonafe M, Olivieri F, Cavallone L, Giovagnetti S, Mayegiani F, Cardelli M, et al. A gender-dependent genetic predisposition to produce high levels of IL-6 is detrimental for longevity. Eur J Immunol. (2001) 31:2357-61. doi: 10. 1002/1521-4141(200108)31:8<2357::AID-IMMU2357>3.0.CO;2-X

31. Marquez EJ, Chung CH, Marches R, Rossi RJ, Nehar-Belaid D, Eroglu A, et al. Sexual-dimorphism in human immune system aging. Nat Commun. (2020) 11:751. doi: 10.1038/s41467-020-14396-9

32. De La Fuente $M$, De Castro NM. Obesity as a model of premature immunosenescence. Curr Immunol Rev. (2012) 8:63-75. doi: 10.2174/157339512798991290

33. Lau EYM, Carroll EC, Callender LA, Hood GA, Berryman V, Pattrick $\mathrm{M}$, et al. Type 2 diabetes is associated with the accumulation of senescent T cells. Clin Exp Immunol. (2019) 197:205-13. doi: 10.1111/ce i. 13344

34. Lee YH, Kim SR, Han DH, Yu HT, Han YD, Kim JH, et al. Senescent T cells predict the development of hyperglycemia in humans. Diabetes. (2019) 68:156-62. doi: 10.2337/db17-1218

35. Appleton SL, Seaborn CJ, Visvanathan R, Hill CL, Gill TK, Taylor AW, et al. Diabetes and cardiovascular disease outcomes in the metabolically healthy obese phenotype: a cohort study. Diabetes Care. (2013) 36:238894. doi: $10.2337 / \mathrm{dc} 12-1971$

36. Jefferies CA. Regulating IRFs in IFN driven disease. Front Immunol. (2019) 10:325. doi: 10.3389/fimmu.2019.00325

37. McNab F, Mayer-Barber K, Sher A, Wack A, O'Garra A. Type I interferons in infectious disease. Nat Rev Immunol. (2015) 15:87-103. doi: 10.1038/nri3787

38. Mantlo E, Bukreyeva N, Maruyama J, Paessler S, Huang C. Antiviral activities of type I interferons to SARS-CoV-2 infection. Antiviral Res. (2020) 179:104811. doi: 10.1016/j.antiviral.2020.104811

39. Stanifer ML, Kee C, Cortese M, Triana S, Mukenhirn M, Kraeusslich HG, et al. Critical role of type III interferon in controlling SARS-CoV-2 infection, replication and spread in primary human intestinal epithelial cells. Cell Rep. (2020) 32:107863. doi: 10.1101/2020.04.24.059667

40. Hadjadj J, Yatim N, Barnabei L, Corneau A, Boussier J, Pere $\mathrm{H}$, et al. Impaired type I interferon activity and exacerbated inflammatory responses in severe Covid-19 patients. Science. (2020) 369:718-24. doi: 10.1101/2020.04.19.20068015

41. Wilk AJ, Rustagi A, Zhao NQ, Roque J, Martinez-Colon GJ, McKechnie JL, et al. A single-cell atlas of the peripheral immune response in patients with severe COVID-19. Nat Med. (2020) 26:1070-6. doi: 10.1038/s41591-020-0944-y

42. Jing Y, Shaheen E, Drake RR, Chen N, Gravenstein S, Deng Y, et al. Aging is associated with a numerical and functional decline in plasmacytoid dendritic cells, whereas myeloid dendritic cells are relatively unaltered in human peripheral blood. Hum Immunol. (2009) 70:77784. doi: 10.1016/j.humimm.2009.07.005

43. Panda A, Qian F, Mohanty S, van Duin D, Newman FK, Zhang L, et al. Age-associated decrease in TLR function in primary human dendritic cells predicts influenza vaccine response. J Immunol. (2010) 184:251827. doi: 10.4049/jimmunol.0901022

44. Agrawal A. Mechanisms and implications of age-associated impaired innate interferon secretion by dendritic cells: a mini-review. Gerontology. (2013) 59:421-6. doi: 10.1159/000350536

45. Metcalf TU, Wilkinson PA, Cameron MJ, Ghneim K, Chiang C, Wertheimer $\mathrm{AM}$, et al. Human monocyte subsets are transcriptionally and functionally altered in aging in response to pattern recognition receptor agonists. $J$ Immunol. (2017) 199:1405-17. doi: 10.4049/jimmunol.1700148

46. Molony RD, Nguyen JT, Kong Y, Montgomery RR, Shaw AC, Iwasaki A. Aging impairs both primary and secondary RIG-I signaling for interferon induction in human monocytes. Sci Signal. (2017) 10:eaan2392. doi: 10.1126/scisignal.aan2392

47. Pillai PS, Molony RD, Martinod K, Dong H, Pang IK, Tal MC, et al. Mx1 reveals innate pathways to antiviral resistance and lethal influenza disease. Science. (2016) 352:463-6. doi: 10.1126/science.aaf3926
48. Canaday DH, Amponsah NA, Jones L, Tisch DJ, Hornick TR, Ramachandra L. Influenza-induced production of interferonalpha is defective in geriatric individuals. J Clin Immunol. (2010) 30:373-83. doi: 10.1007/s10875-010-9374-9

49. Prakash S, Agrawal S, Cao JN, Gupta S, Agrawal A. Impaired secretion of interferons by dendritic cells from aged subjects to influenza : role of histone modifications. Age. (2013) 35:1785-97. doi: 10.1007/s11357-012-9477-8

50. Qian F, Wang X, Zhang L, Lin A, Zhao H, Fikrig E, et al. Impaired interferon signaling in dendritic cells from older donors infected in vitro with West Nile virus. J Infect Dis. (2011) 203:1415-24. doi: 10.1093/infdis/jir048

51. Hayes EB, Komar N, Nasci RS, Montgomery SP, O'Leary DR, Campbell GL. Epidemiology and transmission dynamics of West Nile virus disease. Emerg Infect Dis. (2005) 11:1167-73. doi: 10.3201/eid1108.050289a

52. Montgomery RR, Murray KO. Risk factors for West Nile virus infection and disease in populations and individuals. Expert Rev Anti Infect Ther. (2015) 13:317-25. doi: 10.1586/14787210.2015.1007043

53. Thompson WW, Shay DK, Weintraub E, Brammer L, Cox N, Anderson LJ, et al. Mortality associated with influenza and respiratory syncytial virus in the United States. JAMA. (2003) 289:179-86. doi: 10.1001/jama.289.2.179

54. Channappanavar R, Fehr AR, Vijay R, Mack M, Zhao J, Meyerholz DK, et al. Dysregulated type I interferon and inflammatory monocyte-macrophage responses cause lethal pneumonia in SARS-CoV-infected Mice. Cell Host Microbe. (2016) 19:181-93. doi: 10.1016/j.chom.2016.01.007

55. Channappanavar R, Fehr AR, Zheng J, Wohlford-Lenane C, Abrahante JE, Mack M, et al. IFN-I response timing relative to virus replication determines MERS coronavirus infection outcomes. J Clin Invest. (2019) 130:3625-39. doi: 10.1172/JCI126363

56. Hung IF, Lung KC, Tso EY, Liu R, Chung TW, Chu MY, et al. Triple combination of interferon beta-1b, lopinavir-ritonavir, and ribavirin in the treatment of patients admitted to hospital with COVID-19: an open-label, randomised, phase 2 trial. Lancet. (2020) 395:1695704. doi: 10.1016/S0140-6736(20)31042-4

57. Chen G, Wu D, Guo W, Cao Y, Huang D, Wang H, et al. Clinical and immunological features of severe and moderate coronavirus disease 2019. J Clin Invest. (2020) 130:2620-9. doi: 10.1172/JCI137244

58. Gao Y, Li T, Han M, Li X, Wu D, Xu Y, et al. Diagnostic utility of clinical laboratory data determinations for patients with the severe COVID-19. J Med Virol. (2020) 92:791-6. doi: 10.1002/jmv.25770

59. Herold T, Jurinovic V, Arnreich C, Lipworth BJ, Hellmuth JC, BergweltBaildon MV, et al. Elevated levels of IL- 6 and CRP predict the need for mechanical ventilation in COVID-19. J Allergy Clin Immunol. (2020) 146:128-36.e4. doi: 10.1016/j.jaci.2020.05.008

60. Qin C, Zhou L, Hu Z, Zhang S, Yang S, Tao Y, et al. Dysregulation of immune response in patients with COVID-19 in Wuhan, China. Clin Infect Dis. (2020) 71:762-8. doi: 10.2139/ssrn.3541136

61. Tan M, Liu Y, Zhou R, Deng X, Li F, Liang K, et al. Immunopathological characteristics of coronavirus disease 2019 cases in Guangzhou, China. Immunology. (2020) 160:261-8. doi: 10.1111/imm.13223

62. van Duin M,ohanty S, Thomas V, Ginter S, Montgomery RR, Fikrig E, et al. Age-associated defect in human TLR-1/2 function. J Immunol. (2007) 178:970-5. doi: 10.4049/jimmunol.178.2.970

63. Devevre EF, Renovato-Martins M, Clement K, Sautes-Fridman C, Cremer I, Poitou C. Profiling of the three circulating monocyte subpopulations in human obesity. J Immunol. (2015) 194:3917-23. doi: 10.4049/jimmunol.1402655

64. Dasu MR, Devaraj S, Park S, Jialal I. Increased toll-like receptor (TLR) activation and TLR ligands in recently diagnosed type 2 diabetic subjects. Diabetes Care. (2010) 33:861-8. doi: 10.2337/dc09-1799

65. Farag NS, Breitinger U, Breitinger HG, El Azizi MA. Viroporins and inflammasomes: A key to understand virus-induced inflammation. Int J Biochem Cell Biol. (2020) 122:105738. doi: 10.1016/j.biocel.2020.1 05738

66. Kolahian S, Fernandez IE, Eickelberg O, Hartl D. Immune Mechanisms in Pulmonary Fibrosis. Am J Respir Cell Mol Biol. (2016) 55:30922. doi: 10.1165/rcmb.2016-0121TR

67. Kolb M, Margetts PJ, Anthony DC, Pitossi F, Gauldie J. Transient expression of IL-1beta induces acute lung injury and chronic repair leading to pulmonary fibrosis. J Clin Invest. (2001) 107:1529-36. doi: 10.1172/JCI12568 
68. Wen W, Su W, Tang H, Le W, Zhang X, Zheng Y, et al. Immune cell profiling of COVID-19 patients in the recovery stage by singlecell sequencing. Cell Discov. (2020) 6:31. doi: 10.1038/s41421-0200168-9

69. Ong EZ, Chan YFZ, Leong WY, Lee NMY, Kalimuddin S, Haja Mohideen $\mathrm{SM}$, et al. A dynamic immune response shapes COVID-19 progression. Cell Host Microbe. (2020) 27:879-82.e2. doi: 10.1016/j.chom.2020.03.021

70. Lee HM, Kim JJ, Kim HJ, Shong M, Ku BJ, Jo EK. Upregulated NLRP3 inflammasome activation in patients with type 2 diabetes. Diabetes. (2013) 62:194-204. doi: $10.2337 / \mathrm{db} 12-0420$

71. Ruscitti P, Cipriani P, Di BP, Liakouli V, Berardicurti O, Carubbi F, et al. Monocytes from patients with rheumatoid arthritis and type 2 diabetes mellitus display an increased production of interleukin (IL)-1beta via the nucleotide-binding domain and leucine-rich repeat containing family pyrin 3(NLRP3)-inflammasome activation: a possible implication for therapeutic decision in these patients. Clin Exp Immunol. (2015) 182:3544. doi: $10.1111 /$ cei. 12667

72. Cho SJ, Plataki M, Mitzel D, Lowry G, Rooney K, Stout-Delgado HW. Decreased NLRP3 inflammasome expression in aged lung may contribute to increased susceptibility to secondary Streptococcus pneumoniae infection. Exp Gerontol. (2018) 105:40-6. doi: 10.1016/j.exger.2017.11.010

73. Cho SJ, Rooney K, Choi AMK, Stout-Delgado HW. NLRP3 inflammasome activation in aged macrophages is diminished during Streptococcus pneumoniae infection. Am J Physiol Lung Cell Mol Physiol. (2018) 314:L37287. doi: 10.1152/ajplung.00393.2017

74. Stout-Delgado HW, Vaughan SE, Shirali AC, Jaramillo RJ, Harrod KS. Impaired NLRP3 inflammasome function in elderly mice during influenza infection is rescued by treatment with nigericin. J Immunol. (2012) 188:2815-24. doi: 10.4049/jimmunol.1103051

75. Allen IC, Scull MA, Moore CB, Holl EK, McElvania-TeKippe E, Taxman DJ, et al. The NLRP3 inflammasome mediates in vivo innate immunity to influenza A virus through recognition of viral RNA. Immunity. (2009) 30:556-65. doi: 10.1016/j.immuni.2009.02.005

76. Thomas PG, Dash P, Aldridge JRJr, Ellebedy AH, Reynolds C, Funk AJ, et al. The intracellular sensor NLRP3 mediates key innate and healing responses to influenza A virus via the regulation of caspase-1. Immunity. (2009) 30:566-75. doi: 10.1016/j.immuni.2009.02.006

77. Liu J, Li S, Liu J, Liang B, Wang X, Wang H, et al. Longitudinal characteristics of lymphocyte responses and cytokine profiles in the peripheral blood ofSARS-CoV-2 infected patients EBio Med. (2020) 55:102763. doi: 10.1016/j.ebiom.2020.102763

78. Liu J, Liu Y, Xiang P, Pu L, Xiong H, Li C, et al. Neutrophil-to-lymphocyte ratio predicts critical illness patients with 2019 coronavirus disease in the early stage. J Transl Med. (2020) 18:206. doi: 10.1186/s12967-020-02374-0

79. Song CY, Xu J, He JQ, Lu YQ. COVID-19 early warning score: a multiparameter screening tool to identify highly suspected patients. medRxiv [Preprint]. (2020) doi: 10.1101/2020.03.05.20031906

80. Barnes BJ, Adrover JM, Baxter-Stoltzfus A, Borczuk A, CoolsLartigue J, Crawford JM, et al. Targeting potential drivers of COVID-19: Neutrophil extracellular traps. J Exp Med. (2020) 217:e20200652. doi: 10.1084/jem.20200652

81. Fox SE, Akmatbekov A, Harbert JL, Li G, Quincy BJ, Vander Heide RS. Pulmonary and cardiac pathology in African American patients with COVID-19: an autopsy series from New Orleans. Lancet Respir Med. (2020) 8:681-6. doi: 10.1016/S2213-2600(20)30243-5

82. Zuo Y, Yalavarthi S, Shi H, Gockman K, Zuo M, Madison JA, et al. Neutrophil extracellular traps in COVID-19. JCI Insight. (2020) 5:e138999. doi: 10.1101/2020.04.30.20086736

83. Bendib I, de CL, Granger V, Schlemmer F, Maitre B, Hue S, et al. Neutrophil extracellular traps are elevated in patients with pneumoniarelated acute respiratory distress syndrome. Anesthesiology. (2019) 130:58191. doi: 10.1097/ALN.0000000000002619

84. Lefrancais E, Mallavia B, Zhuo H, Calfee CS, Looney MR. Maladaptive role of neutrophil extracellular traps in pathogen-induced lung injury. JCI Insight. (2018) 3:e98178. doi: 10.1172/jci.insight.98178

85. Lv X, Wen T, Song J, Xie D, Wu L, Jiang X, et al. Extracellular histones are clinically relevant mediators in the pathogenesis of acute respiratory distress syndrome. Respir Res. (2017) 18:165. doi: 10.1186/s12931-017-0651-5
86. Mikacenic C, Moore R, Dmyterko V, West TE, Altemeier WA, Liles WC, et al. Neutrophil extracellular traps (NETs) are increased in the alveolar spaces of patients with ventilator-associated pneumonia. Crit Care. (2018) 22:358. doi: 10.1186/s13054-018-2290-8

87. Aziz M, Fatima R, Assaly R. Elevated interleukin-6 and severe COVID-19: a meta-analysis. J Med Virol. (2020). doi: 10.1002/jmv.25948. [Epub ahead of print].

88. Hazeldine J, Harris P, Chapple IL, Grant M, Greenwood H, Livesey A, et al. Impaired neutrophil extracellular trap formation: a novel defect in the innate immune system of aged individuals. Aging Cell. (2014) 13:6908. doi: 10.1111/acel.12222

89. Tseng CW, Kyme PA, Arruda A, Ramanujan VK, Tawackoli W, Liu GY. Innate immune dysfunctions in aged mice facilitate the systemic dissemination of methicillin-resistant S. aureus PLoS ONE. (2012) 7:e41454. doi: 10.1371/journal.pone.0041454

90. Xu F, Zhang C, Zou Z, Fan EKY, Chen L, Li Y, et al. Aging-related Atg5 defect impairs neutrophil extracellular traps formation. Immunology. (2017) 151:417-32. doi: 10.1111/imm.12740

91. D’Abbondanza M, Martorelli EE, Ricci MA, De VS, Migliola EN, Godino C, et al. Increased plasmatic NETs by-products in patients in severe obesity. Sci Rep. (2019) 9:14678. doi: 10.1038/s41598-019-51220-x

92. Wang L, Zhou X, Yin Y, Mai Y, Wang D, Zhang X. Hyperglycemia induces neutrophil extracellular traps formation through an NADPH oxidase-dependent pathway in diabetic retinopathy. Front Immunol. (2018) 9:3076. doi: 10.3389/fimmu.2018.03076

93. Wong SL, Demers M, Martinod K, Gallant M, Wang Y, Goldfine AB, et al. Diabetes primes neutrophils to undergo NETosis, which impairs wound healing. Nat Med. (2015) 21:815-9. doi: 10.1038/nm.3887

94. Farrera C, Fadeel B. Macrophage clearance of neutrophil extracellular traps is a silent process. J Immunol. (2013) 191:2647-56. doi: 10.4049/jimmunol.1300436

95. Higashimoto Y, Fukuchi Y, Shimada Y, Ishida K, Ohata M, Furuse T, et al. The effects of aging on the function of alveolar macrophages in mice. Mech Ageing Dev. (1993) 69:207-17. doi: 10.1016/0047-6374(93)90024-L

96. Videla LA, Tapia G, Fernandez V. Influence of aging on Kupffer cell respiratory activity in relation to particle phagocytosis and oxidative stress parameters in mouse liver. Redox Rep. (2001) 6:155-9. doi: $10.1179 / 135100001101536265$

97. Wong CK, Smith CA, Sakamoto K, Kaminski N, Koff JL, Goldstein DR. Aging impairs alveolar macrophage phagocytosis and increases influenza-induced mortality in Mice. J Immunol. (2017) 199:10608. doi: 10.4049/jimmunol.1700397

98. Carmona-Gutierrez D, Hughes AL, Madeo F, Ruckenstuhl C. The crucial impact of lysosomes in aging and longevity. Ageing Res Rev. (2016) 32:212. doi: 10.1016/j.arr.2016.04.009

99. Cox LE, Walstein K, Vollger L, Reuner F, Bick A, Dotsch A, et al. Neutrophil extracellular trap formation and nuclease activity in septic patients. $B M C$ Anesthesiol. (2020) 20:15. doi: 10.1186/s12871-019-0911-7

100. Gregoire M, Uhel F, Lesouhaitier M, Gacouin A, Guirriec M, Mourcin F, et al. Impaired efferocytosis and neutrophil extracellular trap clearance by macrophages in ARDS. Eur Respir J. (2018) 52:1702590. doi: 10.1183/13993003.02590-2017

101. Zhu L, Liu L, Zhang Y, Pu L, Liu J, Li X, et al. High level of neutrophil extracellular traps correlates with poor prognosis of severe influenza a infection. J Infect Dis. (2018) 217:428-37. doi: 10.1093/infdis/j ix 475

102. Guan WJ, Ni ZY, Hu Y, Liang WH, Ou CQ, He JX, et al. Clinical characteristics of coronavirus disease 2019 in China. N Engl J Med. (2020) 382:1708-20. doi: 10.1056/NEJMoa2002032

103. Li B, Yang J, Zhao F, Zhi L, Wang X, Liu L, et al. Prevalence and impact of cardiovascular metabolic diseases on COVID-19 in China. Clin Res Cardiol. (2020) 109:531-8. doi: 10.1007/s00392-020-01626-9

104. Honce R, Schultz-Cherry S. Impact of obesity on influenza a virus pathogenesis, immune response, and evolution. Front Immunol. (2019) 10:1071. doi: 10.3389/fimmu.2019.01071

105. Laridan E, Martinod K, De Meyer SF. Neutrophil extracellular traps in arterial and venous thrombosis. Semin Thromb Hemost. (2019) 45:8693. doi: $10.1055 / \mathrm{s}-0038-1677040$ 
106. Saffarzadeh M, Juenemann C, Queisser MA, Lochnit G, Barreto G, Galuska SP, et al. Neutrophil extracellular traps directly induce epithelial and endothelial cell death: a predominant role of histones. PLOS ONE. (2012) 7:e32366. doi: 10.1371/journal.pone.0032366

107. Ali RA, Gandhi AA, Meng H, Yalavarthi S, Vreede AP, Estes SK, et al. Adenosine receptor agonism protects against NETosis and thrombosis in antiphospholipid syndrome. Nat Commun. (2019) 10:1916. doi: 10.1038/s41467-019-09801-x

108. Liu X, Li Z, Liu S, Sun J, Chen Z, Jiang M, et al. Potential therapeutic effects of dipyridamole in the severely ill patients with COVID-19. Acta Pharm Sin B. (2020) 10:1205-15. doi: 10.1016/j.apsb.2020.04.008

109. Merkus PJ, de Hoog M, van Gent R, de Jongste JC. DNase treatment for atelectasis in infants with severe respiratory syncytial virus bronchiolitis. Eur Respir J. (2001) 18:734-7.

110. Nasr SZ, Strouse PJ, Soskolne E, Maxvold NJ, Garver KA, Rubin BK, et al. Efficacy of recombinant human deoxyribonuclease I in the hospital management of respiratory syncytial virus bronchiolitis. Chest. (2001) 120:203-8. doi: 10.1378/chest.120.1.203

111. Sapey E, Greenwood H, Walton G, Mann E, Love A, Aaronson N, et al. Phosphoinositide 3-kinase inhibition restores neutrophil accuracy in the elderly: toward targeted treatments for immunosenescence. Blood. (2014) 123:239-48. doi: 10.1182/blood-2013-08-519520

112. Alba-Loureiro TC, Munhoz CD, Martins JO, Cerchiaro GA, Scavone C, Curi R, et al. Neutrophil function and metabolism in individuals with diabetes mellitus. Braz J Med Biol Res. (2007) 40:1037-44. doi: 10.1590/S0100-879X2006005000143

113. Naghibi M, Smith RP, Baltch AL, Gates SA, Wu DH, Hammer MC, et al. The effect of diabetes mellitus on chemotactic and bactericidal activity of human polymorphonuclear leukocytes. Diabetes Res Clin Pract. (1987) 4:27-35. doi: 10.1016/S0168-8227(87)80030-X

114. Wang Y, Xiao Y, Zhong L, Ye D, Zhang J, Tu Y, et al. Increased neutrophil elastase and proteinase 3 and augmented NETosis are closely associated with beta-cell autoimmunity in patients with type 1 diabetes. Diabetes. (2014) 63:4239-48. doi: 10.2337/db14-0480

115. Zhang D, Guo R, Lei L, Liu H, Wang Y, Wang Y, et al. COVID-19 infection induces readily detectable morphological and inflammationrelated phenotypic changes in peripheral blood monocytes, the severity of which correlate with patient outcome. medRxiv [Preprint]. (2020). doi: 10.1101/2020.03.24.20042655

116. Zhou Y, Fu B, Zheng X, Wang D, Zhao C, Qi Y, et al. Pathogenic T cells and inflammatory monocytes incite inflammatory storm in severe COVID-19 patients. Natl Sci Rev. (2020) 13:nwaa041. doi: 10.1093/nsr/nwaa041

117. Guo C, Li B, Ma H, Wang X, Cai P, Yu Q, et al. Tocilizumab treatment in severe COVID-19 pateints attenuates the inflammatory storm incited by monocyte centric immune interactions revealed by single-cell analysis. Nat Commun. (2020) 11:3924. doi: 10.1038/s41467-020-17834-w

118. Giamarellos-Bourboulis EJ, Netea MG, Rovina N, Akinosoglou K, Antoniadou A, Antonakos N, et al. Complex immune dysregulation in COVID-19 patients with severe respiratory failure. Cell Host Microbe. (2020) 27:992-1000.e3. doi: 10.1016/j.chom.2020.04.009

119. Christou KA, Christou GA, Karamoutsios A, Vartholomatos G, Gartzonika $\mathrm{K}$, Tsatsoulis A, et al. Metabolically healthy obesity is characterized by a proinflammatory phenotype of circulating monocyte subsets. Metab Syndr Relat Disord. (2019) 17:259-65. doi: 10.1089/met.201 8.0132

120. Friedrich K, Sommer M, Strobel S, Thrum S, Bluher M, Wagner U, et al. Perturbation of the monocyte compartment in human obesity. Front Immunol. (2019) 10:1874. doi: 10.3389/fimmu.2019.01874

121. Hearps AC, Martin GE, Angelovich TA, Cheng WJ, Maisa A, Landay $\mathrm{AL}$, et al. Aging is associated with chronic innate immune activation and dysregulation of monocyte phenotype and function. Aging Cell. (2012) 11:867-75. doi: 10.1111/j.1474-9726.2012.00851.x

122. Nyugen J, Agrawal S, Gollapudi S, Gupta S. Impaired functions of peripheral blood monocyte subpopulations in aged humans. J Clin Immunol. (2010) 30:806-13. doi: 10.1007/s10875-010-9448-8

123. Ong SM, Hadadi E, Dang TM, Yeap WH, Tan CT, Ng TP, et al. The pro-inflammatory phenotype of the human non-classical monocyte subset is attributed to senescence. Cell Death Dis. (2018) 9:266. doi: 10.1038/s41419-018-0327-1

124. Poitou C, Dalmas E, Renovato M, Benhamo V, Hajduch F, Abdennour $\mathrm{M}$, et al. CD14dimCD16+ and CD14+CD16+ monocytes in obesity and during weight loss: relationships with fat mass and subclinical atherosclerosis. Arterioscler Thromb Vasc Biol. (2011) 31:2322-30. doi: 10.1161/ATVBAHA.111.230979

125. Rogacev KS, Ulrich C, Blomer L, Hornof F, Oster K, Ziegelin M, et al. Monocyte heterogeneity in obesity and subclinical atherosclerosis. Eur Heart J. (2010) 31:369-76. doi: 10.1093/eurheartj/ehp308

126. Seidler S, Zimmermann HW, Bartneck M, Trautwein C, Tacke F, et al. Age-dependent alterations of monocyte subsets and monocyterelated chemokine pathways in healthy adults. BMC Immunol. (2010) 11:30. doi: 10.1186/1471-2172-11-30

127. Liao M, Liu Y, Yuan J, Wen Y, Xu G, Zhao J, et al. Single-cell landscape of bronchoalveolar immune cells in patients with COVID-19. Nat Med. (2020) 26:842-4. doi: 10.1038/s41591-020-0901-9

128. Kim HM, Lee YW, Lee KJ, Kim HS, and Cho SW, van RN, et al. Alveolar macrophages are indispensable for controlling influenza viruses in lungs of pigs. J Virol. (2008) 82:4265-74. doi: 10.1128/JVI.02602-07

129. McCubbrey AL, Barthel L, Mohning MP, Redente EF, Mould KJ, Thomas $\mathrm{SM}$, et al. Deletion of c-FLIP from CD11b(hi) macrophages prevents development of bleomycin-induced lung fibrosis. Am J Respir Cell Mol Biol. (2018) 58:66-78. doi: 10.1165/rcmb.2017-0154OC

130. Morales-Nebreda L, Misharin AV, Perlman H, Budinger GR. The heterogeneity of lung macrophages in the susceptibility to disease. Eur Respir Rev. (2015) 24:505-9. doi: 10.1183/16000617.003 1-2015

131. Glass WG, Subbarao K, Murphy B, Murphy PM. Mechanisms of host defense following severe acute respiratory syndrome-coronavirus (SARS-CoV) pulmonary infection of mice. J Immunol. (2004) 173:40309. doi: 10.4049/jimmunol.173.6.4030

132. Wang W Jr, He J, Lie P, Huang L, Wu S, Lin Y, et al. The definition and risks of cytokine release syndrome-like in 11 covid-19-infected pneumonia critically ill patients: disease characteristics and retrospective analysis. medRxiv [Preprint]. (2020) doi: 10.1101/2020.02.26.20026989

133. Wang F, Nie J, Wang H, Zhao Q, Xiong Y, Deng L, et al. Characteristics of peripheral lymphocyte subset alteration in COVID-19 pneumonia. J Infect Dis. (2020) 221:1762-9. doi: 10.1093/infdis/jiaa150

134. Zheng M, Gao Y, Wang G, Song G, Liu S, Sun D, et al. Functional exhaustion of antiviral lymphocytes in COVID-19 patients. Cell Mol Immunol. (2020) 17:533-5. doi: 10.1038/s41423-020-0402-2

135. Brady J, Hayakawa Y, Smyth MJ, Nutt SL. IL-21 induces the functional maturation of murine NK cells. J Immunol. (2004) 172:2048-58. doi: 10.4049/jimmunol.172.4.2048

136. Andre P, Denis C, Soulas C, Bourbon-Caillet C, Lopez J, Arnoux T, et al. Anti-NKG2A mAb is a checkpoint inhibitor that promotes anti-tumor immunity by unleashing both T, and NK cells. Cell. (2018) 175:173143. doi: 10.1016/j.cell.2018.10.014

137. Gornalusse GG, Hirata RK, Funk SE, Riolobos L, Lopes VS, Manske G, et al. HLA-E-expressing pluripotent stem cells escape allogeneic responses and lysis by NK cells. Nat Biotechnol. (2017) 35:765-72. doi: 10.1038/nbt.3860

138. Hazeldine J, Hampson P, Lord JM. Reduced release and binding of perforin at the immunological synapse underlies the age-related decline in natural killer cell cytotoxicity. Aging Cell. (2012) 11:7519. doi: 10.1111/j.1474-9726.2012.00839.x

139. Mariani E, Pulsatelli L, Meneghetti A, Dolzani P, Mazzetti I, Neri S, et al. Different IL-8 production by T and NK lymphocytes in elderly subjects. Mech Ageing Dev. (2001) 122:1383-95. doi: 10.1016/S0047-6374(01)00270-6

140. Mariani E, Meneghetti A, Neri S, Ravaglia G, Forti P, Cattini $\mathrm{L}$, et al. Chemokine production by natural killer cells from nonagenarians. Eur J Immunol. (2002) 32:1524-29. doi: 10.1002/15214141(200206)32:6<1524::AID-IMMU1524>3.0.CO;2-E

141. Mariani E, Pulsatelli L, Neri S, Dolzani P, Meneghetti A, Silvestri T, et al. RANTES and MIP-1alpha production by T lymphocytes, monocytes and NK cells from nonagenarian subjects. Exp Gerontol. (2002) 37:21926. doi: 10.1016/S0531-5565(01)00187-5 
142. Long EO, Kim HS, Liu D, Peterson ME, Rajagopalan S. Controlling natural killer cell responses: integration of signals for activation and inhibition. Annu Rev Immunol. (2013) 31:227-58. doi: 10.1146/annurev-immunol-020711-075005

143. Le Garff-Tavernier M, Beziat V, Decocq J, Siguret V, Gandjbakhch F, Pautas E, et al. Human NK cells display major phenotypic and functional changes over the life span. Aging Cell. (2010) 9:527-35. doi: 10.1111/j.1474-9726.2010.00584.x

144. Almeida-Oliveira A, Smith-Carvalho M, Porto LC, Cardoso-Oliveira J, Ribeiro AS, Falcao RR, et al. Age-related changes in natural killer cell receptors from childhood through old age. Hum Immunol. (2011) 72:31929. doi: 10.1016/j.humimm.2011.01.009

145. Tarazona R, Gayoso I, Corona A, Luisa Pita M, Peralbo E, Casado JG, et al. NK cells in human ageing. In: Fulop T, Franceschi C, Hirokawa K, Pawelec G, editors. Handbook on Immunosenescence. Dordrecht: Springer (2012) p. 531-44. doi: 10.1007/978-1-4020-9063-9_27

146. Chen X, Zhao B, Qu Y, Chen Y, Xiong J, Feng Y, et al. Detectable serum SARSCoV-2 viral load (RNAaemia) is closely correlated with drastically elevated interleukin 6 (IL-6) level in critically ill COVID-19 patients. Clin Infect Dis. (2020) ciaa449. doi: 10.1101/2020.02.29.20029520. [Epub ahead of print].

147. Cifaldi L, Prencipe G, Caiello I, Bracaglia C, Locatelli F, De BF, et al. Inhibition of natural killer cell cytotoxicity by interleukin-6: implications for the pathogenesis of macrophage activation syndrome. Arthritis Rheumatol. (2015) 67:3037-46. doi: 10.1002/art.39295

148. Ivagnes A, Messaoudene M, Stoll G, Routy B, Fluckiger A, Yamazaki $\mathrm{T}$, et al. TNFR2/BIRC3-TRAF1 signaling pathway as a novel NK cell immune checkpoint in cancer. Oncoimmunology. (2018) 7:e1386826. doi: 10.1080/2162402X.2017.1386826

149. Wu J, Gao FX, Wang C, Qin M, Han F, Xu T, et al. IL-6 and IL-8 secreted by tumour cells impair the function of NK cells via the STAT3 pathway in oesophageal squamous cell carcinoma. J Exp Clin Cancer Res. (2019) 38:321. doi: 10.1186/s13046-019-1310-0

150. Kamiya T, Seow SV, Wong D, Robinson M, Campana D. Blocking expression of inhibitory receptor NKG2A overcomes tumor resistance to NK cells. JClin Invest. (2019) 129:2094-106. doi: 10.1172/JCI123955

151. van Hall T, André P, Horowitz A, Ruan DF, and Borst L, Zerbib R, et al. Monalizumab: inhibiting the novel immune checkpoint NKG2A. $J$ Immunother Cancer. (2019) 7:263. doi: 10.1186/s40425-019-0761-3

152. Yaqinuddin A, Kashir J. Innate immunity in COVID-19 patients mediated by NKG2A receptors, and potential treatment using Monalizumab, Cholroquine, and antiviral agents. Med Hypotheses. (2020) 140:109777. doi: 10.1016/j.mehy.2020.109777

153. Wan S, Yi Q, Fan S, Lv J, Zhang X, Guo L, et al. Characteristics of lymphocyte subsets and cytokines in peripheral blood of 123 hospitalized patients with 2019 novel coronavirus pneumonia (NCP). medRxiv [Preprint]. (2020). doi: $10.1101 / 2020.02 .10 .20021832$

154. Diao B, Wang C, Tan Y, Chen X, Liu Y, Ning L, et al. Reduction and functional exhaustion of $\mathrm{T}$ cells in patients with coronavirus disease 2019 (COVID-19). Front Immunol. (2020) 11:827. doi: 10.3389/fimmu.2020.00827

155. Braun J, Loyal L, Frentsch M, Wendisch D, Georg P, Kurth F, et al. Presence of SARS-CoV-2 reactive T cells in COVID-19 patients and healthy donors. medRxiv [Preprint]. (2020). doi: 10.1101/2020.04.17.20061440

156. De Biasi S, Meschiari M, Gibellini L, Bellinazzi C, Borella R, Fidanza $\mathrm{L}$, et al. Marked T cell activation, senescence, exhaustion and skewing towards TH17 in patients with COVID-19 pneumonia. Nat Commun. (2020) 11:3434. doi: 10.21203/rs.3.rs-23957/v1

157. Thevarajan I, Nguyen THO, Koutsakos M, Druce J, Caly L, van de Sandt $\mathrm{CE}$, et al. Breadth of concomitant immune responses prior to patient recovery: a case report of non-severe COVID-19. Nat Med. (2020) 26:4535. doi: 10.1038/s41591-020-0819-2

158. Zheng HY, Zhang M, Yang CX, Zhang N, Wang XC, Yang XP, et al. Elevated exhaustion levels and reduced functional diversity of $\mathrm{T}$ cells in peripheral blood may predict severe progression in COVID-19 patients. Cell Mol Immunol. (2020) 17:541-3. doi: 10.1038/s41423-020-0401-3

159. Yang X, Dai T, Zhou X, Qian H, Guo R, Lei L, et al. Analysis of adaptive immune cell populations and phenotypes in the patients infected by SARSCoV-2. medRxiv [Preprint]. (2020). doi: 10.1101/2020.03.23.20040675
160. Yang H, Youm YH, Sun Y, Rim JS, Galban CJ, Vandanmagsar B. Axin expression in thymic stromal cells contributes to an age-related increase in thymic adiposity and is associated with reduced thymopoiesis independently of ghrelin signaling. J Leukoc Biol. (2009) 85:92838. doi: 10.1189/jlb.1008621

161. Fagnoni FF, Vescovini R, Passeri G, Bologna G, Pedrazzoni M, Lavagetto $\mathrm{G}$, et al. Shortage of circulating naive $\mathrm{CD} 8(+) \mathrm{T}$ cells provides new insights on immunodeficiency in aging. Blood. (2000) 95:28608. doi: 10.1182/blood.V95.9.2860.009k35_2860_2868

162. Naylor K, Li G, Vallejo AN, Lee WW, Koetz K, Bryl E, et al. The influence of age on T cell generation and TCR diversity. J Immunol. (2005) 174:744652. doi: $10.4049 /$ jimmunol.174.11.7446

163. Yang H, Youm YH, Vandanmagsar B, Rood J, Kumar KG, Butler AA, et al. Obesity accelerates thymic aging. Blood. (2009) 114:380312. doi: 10.1182/blood-2009-03-213595

164. Larbi A, Douziech N, Dupuis G, Khalil A, Pelletier H, Guerard KP, et al. Age-associated alterations in the recruitment of signal-transduction proteins to lipid rafts in human T lymphocytes. J Leukoc Biol. (2004) 75:37381. doi: $10.1189 /$ jlb.0703319

165. Quadri RA, Plastre O, Phelouzat MA, Arbogast A, Proust JJ. Age-related tyrosine-specific protein phosphorylation defect in human T lymphocytes activated through CD3, CD4, CD8 or the IL-2 receptor. Mech Ageing Dev. (1996) 88:125-38. doi: 10.1016/0047-6374(96)01715-0

166. Deng Y, Jing Y, Campbell AE, Gravenstein S. Age-related impaired type $1 \mathrm{~T}$ cell responses to influenza: reduced activation ex vivo, decreased expansion in CTL culture in vitro, and blunted response to influenza vaccination in vivo in the elderly. I Immunol. (2004) 172:343746. doi: 10.4049/jimmunol.172.6.3437

167. Smithey MJ, Renkema KR, Rudd BD, Nikolich-Zugich J. Increased apoptosis, curtailed expansion and incomplete differentiation of CD8+ T cells combine to decrease clearance of L. monocytogenes in old mice. Eur J Immunol. (2011) 41:1352-64. doi: 10.1002/eji.201041141

168. Duggal NA, Pollock RD, Lazarus NR, Harridge S, Lord JM. Major features of immunesenescence, including reduced thymic output, are ameliorated by high levels of physical activity in adulthood. Aging Cell. (2018) 17:e12750. doi: 10.1111/acel.12750

169. Wang Z, Aguilar EG, Luna JI, Dunai C, Khuat LT, Le CT, et al. Paradoxical effects of obesity on $\mathrm{T}$ cell function during tumor progression and PD-1 checkpoint blockade. Nat Med. (2019) 25:141-51. doi: 10.1038/s41591-018-0221-5

170. Yi HS, Kim SY, Kim JT, Lee YS, Moon JS, Kim M, et al. T-cell senescence contributes to abnormal glucose homeostasis in humans and mice. Cell Death Dis. (2019) 10:249. doi: 10.1038/s41419-019-1494-4

171. Weng NP, Akbar AN, Goronzy J. CD28(-) T cells: their role in the ageassociated decline of immune function. Trends Immunol. (2009) 30:30612. doi: 10.1016/j.it.2009.03.013

172. Saurwein-Teissl M, Lung TL, Marx F, Gschosser C, Asch E, Blasko I, et al. Lack of antibody production following immunization in old age: association with $\mathrm{CD} 8(+) \mathrm{CD} 28(-) \mathrm{T}$ cell clonal expansions and an imbalance in the production of Th1 and Th2 cytokines. J Immunol. (2002) 168:58939. doi: $10.4049 /$ jimmunol.168.11.5893

173. van Duin D, Allore HG, Mohanty S, Ginter S, Newman FK, Belshe RB. Prevaccine determination of the expression of costimulatory B7 molecules in activated monocytes predicts influenza vaccine responses in young and older adults. J Infect Dis. (2007) 195:1590-97. doi: 10.1086/ 516788

174. Luzi L, Radaelli G. MInfluenza and obesity: its odd relationship and the lessons for COVID-19 pandemic. Acta Diabetol. (2020) 57:75964. doi: 10.1007/s00592-020-01522-8

175. Kuri-Cervantes L, Pampena MB, Meng W, Rosenfeld AM, Ittner CAG, Weisman AR, et al. Comprehensive mapping of immune pertubations associated with severe COVID-19. Sci Immunol. (2020) 5:eabd7114. doi: 10.1126/sciimmunol.abd7114

176. Laing AG, Lorenc A, Del Barrio IDM, Das A, Fish M, Monin L, et al. A consensus COVID-19 immune signature combines immuno-protection with discrete sepsis-like traits associated with poor prognosis. medRxiv [Preprint]. (2020) doi: 10.1101/2020.06.08.20125112 
177. Mathew D, Giles JR, Baxter AE, Oldridge DA, Greenplate AR, Wu JE, et al. Deep immune profiling of COVID-19 patients reveals distinct immunotypes with therapeutic implications. Science. (2020) 369:eabc8511. doi: 10.1126/science.abc8511

178. Zhao J, Yuan Q, Wang H, Liu W, Liao X, Su Y, et al. Antibody responses to SARS-CoV-2 in patients of novel coronavirus disease 2019. Clin. Infect. Dis. (2020) ciaa344. doi: 10.2139/ssrn.3546052. [Epub ahead of print].

179. Shen C, Wang Z, Zhao F, Yang Y, Li J, Yuan J, et al. Treatment of 5 critically ill patients with COVID-19 with convalescent plasma. JAMA. (2020) 323:15829. doi: 10.1001/jama.2020.4783

180. Xiao AT, Gao C, Zhang S. Profile of specfic antibodies to SARS-CoV-2: the first report. J Infect. (2020) 81:147-78. doi: 10.1016/j.jinf.2020.03.012

181. Cao WU, Liu W, Zhang PH, Zhang F, Richardus JH. Disappearance of antibodies to SARS-associated coronavirus after recovery. $N$ Engl J Med. (2007) 357:1162-3. doi: 10.1056/NEJMc070348

182. Tang F, Quan Y, Xin ZT, Wrammert J, Ma MJ, Lv H. Lack of peripheral memory B cell responses in recovered patients with severe acute respiratory syndrome: a six-year follow-up study. J Immunol. (2011) 186:72648. doi: 10.4049/jimmunol.0903490

183. Ademokun $\mathrm{A}, \mathrm{Wu} \mathrm{YC}$, Dunn-Walters D. The ageing $\mathrm{B}$ cell population: composition and function. Biogerontology. (2010) 11:125-37. doi: 10.1007/s10522-009-9256-9

184. Frasca D, Landin AM, Lechner SC, Ryan JG, Schwartz R, Riley RL, et al. Aging down-regulates the transcription factor E2A, activation-induced cytidine deaminase, and Ig class switch in human B cells. J Immunol. (2008) 180:5283-90. doi: 10.4049/jimmunol.180.8.5283

185. Veneri D, Ortolani R, Franchini M, Tridente G, Pizzolo G, Vella A. Expression of CD27 and CD23 on peripheral blood B lymphocytes in humans of different ages. Blood Transfus. (2009) 7:29-34. doi: 10.2450/2008.0007-08

186. Shi Y, Yamazaki T, Okubo Y, Uehara Y, Sugane K, Agematsu K. Regulation of aged humoral immune defense against pneumococcal bacteria by igM memory B cell. J Immunol. (2005) 175:3262-7. doi: 10.4049/jimmunol.175.5.3262

187. Frasca D, Nguyen D, Riley RL, Blomberg BB. Effects of aging on proliferation and E47 transcription factor activity induced by different stimuli in murine splenic B cells. Mech Ageing Dev. (2003) 124:3619. doi: 10.1016/S0047-6374(03)00009-5

188. Yang X, Stedra J, Cerny J. Relative contribution of $\mathrm{T}$ and $\mathrm{B}$ cells to hypermutation and selection of the antibody repertoire in germinal centers of aged mice. J Exp Med. (1996) 183:959-70. doi: 10.1084/jem.18 3.3 .959

189. Frasca D, Riley RL, Blomberg BB. Humoral immune response and B-cell functions including immunoglobulin class switch are downregulated in aged mice and humans. Semin Immunol. (2005) 17:378-84. doi: 10.1016/j.smim.2005.05.005

190. Frasca D, Put E, Riley RL, Blomberg BB. Reduced Ig class switch in aged mice correlates with decreased E47 and activation-induced cytidine deaminase. $J$ Immunol. (2004) 172:2155-62. doi: 10.4049/jimmunol.172.4.2155

191. Frasca D, Put E, Landin AM, Gong D, Riley RL, Blomberg BB. RNA stability of the E2A- and encoded transcription factor E47 is lower in splenic activated B cells from aged mice. J Immunol. (2005) 175:663344. doi: 10.4049/jimmunol.175.10.6633

192. Aydar Y, Balogh P, Tew JG, Szakal AK. Altered regulation of FC gamma RII on aged follcular dendritic cells correlates with immunoreceptor tyrosine-based inhibition motif signaling in B cells and reduced germinal center formation. J Immunol. (2003) 171:5975-87. doi: 10.4049/jimmunol.171.11.5975

193. Eaton SM, Burns EM, Kusser K, Randall TD, Haynes L. Age-related defects in $\mathrm{CD} 4 \mathrm{~T}$ cell cognate helper function lead to reductions in humroal responses. J Exp Med. (2004) 200:1613-22. doi: 10.1084/jem.20041395

194. Hannoun C, Megas F, Piercy J. Immunogenicity and protective efficacy of influenza vaccination. Virus Res. (2004) 103:1338. doi: 10.1016/j.virusres.2004.02.025

195. Looney RJ, Hasan MS, Coffin D, Campbell D, Falsey AR, Kolassa J, et al. Hepatitis B immunization of healthy elderly adults: relationship between naïve $\mathrm{CD} 4+\mathrm{T}$ cells and primary immune response and evaluation of GM-CSF as an adjuvant. J Clin Immunol. (2001) 21:306. doi: 10.1023/A:1006736931381

196. Wolters B, Junge U, Dziuba S, Roggendorf M. Immunogenicity of combined hepatitis A and B vaccine in elderly persons. Vaccine. (2003) 21:36238. doi: 10.1016/S0264-410X(03)00399-2

197. Murasko DM, Bernstein ED, Gardner EM, Gross P, Munk G, Dran S, et al. Role of humoral and cell-mediated immunity in protection from influenza disease after immunization of healthy elderly. Exp Gerontol. (2002) 37:42739. doi: 10.1016/S0531-5565(01)00210-8

198. Hainz U, Jenewein B, Asch E, Pfeiffer KP, Berger P, Grubeck-Loebenstein B. Insufficient protection for healthy elderly adults by tetanus and TBE vaccines. Vaccine. (2005) 23:3232-5. doi: 10.1016/j.vaccine.2005.01.085

199. Coe CL, Lubach GR, Kinnard J. Immune senescence in old and very old rhesus monkeys: reduced antibody response to influenza vaccination. Age. (2012) 34:1169-77. doi: 10.1007/s11357-011-9356-8

200. Taylor DN, Treanor JJ, Strout C, Johnson C, Fitzgerald T, Kavita U, et al. Induction of a potent immune response in the elderly using the TLR-5 agonist, flagelling, with a recombinant hemagglutinin influenzaflagellin fusion vaccine (VAX125, STF2.HA1 SI). Vaccine. (2011) 29:4897902. doi: 10.1016/j.vaccine.2011.05.001

201. Franceschi C, Bonafe M, Valensin S, Olivieri F, De LM, Ottaviani E, et al. Inflamm-aging. An evolutionary perspective on immunosenescence Ann N Y Acad Sci. (2000) 908:244-54. doi: 10.1111/j.1749-6632.2000.tb06651.x

202. Bonafe M, Prattichizzo F, Giuliani A, Storci G, Sabbatinelli J, Olivieri F. Inflamm-aging: why older men are the most susceptible to SARSCoV-2 complicated outcomes. Cytokine Growth Factor Rev. (2020) 53:337. doi: 10.1016/j.cytogfr.2020.04.005

203. Mueller AL, McNamara MS, Sinclair DA. Why does COVID-19 disproportionately affect older people? Aging. (2020) 12:995981. doi: 10.20944/preprints202004.0548.v1

204. Chambers ES, Vukmanovic-Stejic M, Shih BB, Trahair H, Subramanian P, Devine OP, et al. (2020) Monocyte-derived prostaglandin E2 inhibits antigen-specific cutaenous immunity during ageing. bioRxiv [Preprint]. doi: 10.1101/2020.04.02.020081

205. Vukmanovic-Stejic M, Chambers ES, Suarez-Farinas M, Sandhu D, Fuentes-Duculan J, Patel N. Enhancement of cutaneous immunity during aging by blocking p38 mitogen-activated protein (MAP) kinase-induced inflammation. J Allergy Clin Immunol. (2018) 142:844-56. doi: 10.1016/j.jaci.2017.10.032

206. Cope AP, Liblau RS, Yang XD, Congia M, Laudanna C, Schreiber $\mathrm{RD}$, et al. Chronic tumor necrosis factor alters $\mathrm{T}$ cell responses by attenuating $\mathrm{T}$ cell receptor signaling. J Exp Med. (1997) 185:157384. doi: 10.1084/jem.185.9.1573

207. Agius E, Lacy KE, Vukmanovic-Stejic M, Jagger AL, Papageorgiou AP, Hall $\mathrm{S}$, et al. Decreased TNF-alpha synthesis by macrophages restricts cutaneous immunosurveillance by memory CD4+ T cells during aging. J Exp Med. (2009) 206:1929-40. doi: 10.1084/jem.20090896

208. Meyer KC, Ershler W, Rosenthal NS, Lu XG, Peterson K. Immune dysregulation in the aging human lung. Am J Respir Crit Care Med. (1996) 153:1072-9. doi: 10.1164/ajrccm.153.3.8630547

209. Moliva JI, Rajaram MV, Sidiki S, Sasindran SJ, Guirado E, Pan XJ, et al. Molecular composition of the alveolar lining fluid in the aging lung. Age. (2014) 36:9633. doi: 10.1007/s11357-014-9633-4

210. Parikh P, Wicher S, Khandalavala K, Pabelick CM, Britt RDJr, Prakash YS. Cellular senescence in the lung across the age spectrum. Am J Physiol Lung Cell Mol Physiol. (2019) 316:L826-L842. doi: 10.1152/ajplung.004 24.2018

211. Wang C, Jurk D, Maddick M, Nelson G, Martin-Ruiz C, von Zglinicki T. DNA damage response and cellular senescence in tissues of aging mice. Aging Cell. (2009) 8:311-23. doi: 10.1111/j.1474-9726.2009.00481.x

212. Zhou Z, Ren L, Zhang L, Zhong J, Xiao Y, Jia Z, et al. Heightened innate immune responses in the respiratory tract of COVID-19 patients. Cell Host Microbe. (2020) 27:883-890.e2. doi: 10.1016/j.chom.2020.04.017

213. Acosta JC, Banito A, Wuestefeld T, Georgilis A, Janich P, Morton JP, et al. A complex secretory program orchestrated by the inflammasome controls paracrine senescence. Nat Cell Biol. (2013) 15:978-90. doi: 10.1038/nc b2784 
214. Ohgo S, Hasegawa S, Hasebe Y, Mizutani H, Nakata S, Akamatsu H. Senescent dermal fibroblasts enhance stem cell migration through CCL2/CCR2 axis. Exp Dermatol. (2015) 24:552-4. doi: 10.1111/exd.12701

215. Coppe JP, Patil CK, Rodier F, Sun Y, Munoz DP, Goldstein J, et al. Senescenceassociated secretory phenotype reveale cell-nonautonomous functions of oncogenic RAS and the p53 tumor suppressor. PLoS Biol. (2008) 6:285368. doi: 10.1371/journal.pbio.0060301

216. Dimri GP, Lee X, Basile G, Acosta M, Scott G, Roskelley C, et al. A biomarker that identifies senescent human cells in culture and in aging skin in vivo. Proc Natl Acad Sci USA. (1995) 26:9363-7. doi: 10.1073/pnas.92.20.9363

217. Martin JA, Buckwalter JA. Telomere erosion and senescence in human articular cartilage chondrocytes. J Gerontol A Biol Sci Med Sci. (2001) 56:B172-9. doi: 10.1093/gerona/56.4.B172

218. Minamino T, Orimo M, Shimizu I, Kunieda T, Yokoyama M, Ito T, et al. A crucial role for adipose tissue p53 in the regulation of insulin resistance. Nat Med. (2009) 15:1082-7. doi: 10.1038/nm.2014

219. Kim JA, Seong RK, Shin OS. Enhanced viral replication by cellular replicative senescence. Immune Netw. (2016) 16:286-95. doi: 10.4110/in.2016.16.5.286

220. Yu YTC, Chien SC, Chen IY, Lai CT, Tsay YG, Chang SC, et al. Surface vimentin is critical for the cell entry of SARS-CoV. J Biomed Sci. (2016) 23:14. doi: 10.1186/s12929-016-0234-7

221. Frescas D, Roux CM, Aygun-Sunar S, Gleiberman AS, Krasnov P, Kurnasov $\mathrm{OV}$, et al. Senescent cells expose and secrete an oxidized form of membranebound vimentin as revealed by a natural polyreactive antibody. Proc Natl Acad Sci USA. (2017) 114:E1668-E77. doi: 10.1073/pnas.1614661114

222. Chapagain P. Potential role of cellular senescence on coronavirus infections. Preprints. (2020) doi: 10.20944/preprints202004.0532.v1

223. Malavolta M, Giacconi R, Brunetti D, Provinciali M, Maggi F. Exploring the relevance of senotherapeutics for the current SARSCoV-2 emergency and similar future global health threats. Cells. (2020) 9:909. doi: 10.3390/cells9040909

224. Sargiacomo C, Sotgia F, Lisanti P. MCOVID-19 and chronological aging: senolytics and other anti-aging drugs for the treatment or prevention of conroa virus infection? Aging. (2020) 12:6511-7. doi: 10.18632/aging.103001

225. De Maeyer RPH, van de Merwe RC, Louie R, Bracken OV, Devine OP, Goldstein DR, et al. Blocking elevated p38 MAPK restores efferocytosis and inflammatory resolution in the elderly. Nat Immunol. (2020) 21:61525. doi: 10.1038/s41590-020-0646-0

226. Vellas C, Delobel P, de Souto Barreto P, Izopet J. COVID-19, virology geroscience: a perspective. J Nutr Health Aging. (2020) 24:1-7. doi: 10.1007/s12603-020-1416-2

227. Dilek N, Silly RV, Blancho G, Vanhove B. Myeloid-derived suppressor cells: mechanisms of action and recent advances in their role in transplant tolerance. Front Immunol. (2012) 3:208. doi: 10.3389/fimmu.2012.00208

228. Salminen A, Kaarniranta K, Kauppinen A. Immunosenescence: the potential role of myeloid-derived suppressor cells (MDSC) in age-related immune deficiency. Cell Mol Life Sci. (2019) 76:1901-18. doi: 10.1007/s00018-019-03048-x

229. Salminen A, Kaarniranta K, Kauppinen A. The role of myeloid-derived suppressor cells (MDSC) in the inflammaging process. Ageing Res Rev. (2018) 48:1-10. doi: 10.1016/j.arr.2018.09.001

230. Bao Y, Mo J, Ruan L, Li G. Increased monocytic CD14+HLADRlow/myeloid-derived suppressor cells in obesity. Mol Med Rep. (2015) 11:23228. doi: 10.3892/mmr.2014.2927

231. Fernandez-Ruiz JC, Avila JCG, Martinez-Fierro ML, Garza-Veloz I, Cervantes-Villagrana AR, Valtierra-Alvarado MA. Myeloidderived suppressor cells show different frequencies in diabetics subjects with arterial hypertension. J Diabetes Res. (2019) 2019:1568457. doi: 10.1155/2019/1568457

232. Verschoor CP, Johnstone J, Millar J, Dorrington MG, Habibagahi M, Lelic A, et al. Blood CD33(+)HLA-DR(-) myeloid-derived suppressor cells are increased with age and a history of cancer. J Leukoc Biol. (2013) 93:6337. doi: 10.1189/jlb.0912461

233. Bueno V, Sant'Anna OA, Lord JM. Ageing and myeloid-derived suppressor cells: possible involvement in immunosenescence and age-related disease. Age. (2014) 36:9729. doi: 10.1007/s11357-014-9729-x

234. Veglia F, Perego M, Gabrilovich D. Myeloid-derived suppressor cells coming of age. Nat Immunol. (2018) 19:108-19. doi: 10.1038/s41590-017-0022-x
235. Bordoni V, Sacchi A, Cimini E, Notari S, Grassi G, Tartaglia E, et al. An inflammatory profile correlates with decreased frequency of cytotoxic cells in coronavirus disease 2019. Clin. Infect. Dis. (2020) ciaa577. doi: $10.1093 / \mathrm{cid} /$ ciaa577

236. Agrati C, Sacchi A, Bordoni V, Cimini E, Notari S, Grassi G, et al. Expansion of myeloid-derived suppressor cells in patients with severe coronavirus disease (COVID-19). Cell Death Differ. (2020) doi: 10.1038/s41418-020-0572-6. [Epub ahead of print].

237. Schulte-Schrepping J, Reusch N, Paclik D, Babler K, Schlickeiser S, Zhang B, et al. Suppressive myeloid cells are a hallmark of severe COVID-19. medRxiv [Preprint]. (2020) doi: 10.1101/2020.06.03.20119818

238. Corsini E, Battaini F, Lucchi L, Marinovich M, Racchi M, Govoni S, et al. A defective protein kinase $\mathrm{C}$ anchoring system underlying age-associated impairment in TNF-alpha production in rat macrophages. I Immunol. (1999) 163:3468-73

239. Hinojosa CA, Akula Suresh BR, Rahman MM, Fernandes G Boyd AR, Orihuela CJ. Elevated A20 contributes to age-dependent macrophage dysfunction in the lungs. ExpGerontol. (2014) 54:58-66. doi: 10.1016/j.exger.2014.01.007

240. Wong TM, Boyapalle S, Sampayo V, Nguyen HD, Bedi R, Kamath SG, et al. Respiratory syncytial virus (RSV) infection in elderly mice results in altered antiviral gene expression and enhanced pathology. PLoS ONE. (2014) 9:e88764. doi: 10.1371/journal.pone.0088764

241. Nogusa S, Ritz BW, Kassim SH, Jennings SR, Gardner EM. Characterization of age-related changes in natural killer cells during primary influenza infection in mice. Mech geing Dev. (2008) 129:223-30. doi: 10.1016/j.mad.2008.01.003

242. Zhao J, Zhao J, Legge K, Perlman S. Age-related increases in PGD(2) expression impair respiratory DC migration, resulting in diminished $\mathrm{T}$ cell responses upon respiratory virus infection in mice. J Clin Invest. (2011) 121:4921-30. doi: 10.1172/JCI59777

243. Jiang J, Fisher EM, Murasko DM. CD8 T cell responses to influenza virus infection in aged mice. Ageing ResRev. (2011) 10:422-7. doi: 10.1016/j.arr.2011.02.001

244. Po JL, Gardner EM, Anaraki F, Katsikis PD, Murasko DM. Age-associated decrease in virus-specific CD8+ $\mathrm{T}$ lymphocytes during primary influenza infection. Mech Ageing Dev. (2002) 123:1167-81. doi: 10.1016/S0047-6374(02)00010-6

245. Toapanta FR, Ross TM. Impaired immune responses in the lungs of aged mice following influenza infection. Respir Res. (2009) 10:112. doi: 10.1186/1465-9921-10-112

246. Baas T, Roberts A, Teal TH, Vogel L, Chen J, Tumpey TM, et al. Genomic analysis reveals age-dependent innate immune responses to severe acute respiratory syndrome coronavirus. J Virol. (2008) 82:946576. doi: 10.1128/JVI.00489-08

247. Clay CC, Donart N, Fomukong N, Knight JB, Overheim K, Tipper J, et al. Severe acute respiratory syndrome-coronavirus infection in aged nonhuman primates is associated with modulated pulmonary and systemic immune responses. Immun Ageing. (2014) 11:4. doi: 10.1186/1742-493 3-11-4

248. Nagata $N$, Iwata $N$, Hasegawa $H$, Fukushi S, Harashima A, Sato $\mathrm{Y}$, et al. Mouse-passaged severe acute respiratory syndrome-associated coronavirus leads to lethal pulmonary edema and diffuse alveolar damage in adult but not young mice. Am J Pathol. (2008) 172:162537. doi: 10.2353/ajpath.2008.071060

249. Smits SL, de LA, van den Brand JM, Leijten LM, van IJcken WF, Eijkemans MJ, et al. Exacerbated innate host response to SARS-CoV in aged non-human primates. PLoS Pathog. (2010) 6:e1000756. doi: 10.1371/journal.ppat.1000756

250. Yu P, Qi F, Xu Y, Li F, Liu P, Liu J, et al. Age-related rhesus macaque models of COVID-19. Animal Model Exp Med. (2020) 3:93-7. doi: 10.1002/ame2.12108

251. Zhao J, Wohlford-Lenane C, Zhao J, Fleming E, Lane TE, McCray $\mathrm{PBJr}$, et al. Intranasal treatment with poly $\left(\mathrm{I}^{*} \mathrm{C}\right)$ protects aged mice from lethal respiratory virus infections. J Virol. (2012) 86:1141624. doi: 10.1128/JVI.01410-12

252. Sugimoto MA, Sousa LP, Pinho V, Perretti M, Teixeira MM. Resolution of inflammation: what controls its onset? Front Immunol. (2016) 7:160. doi: 10.3389/fimmu.2016.00160 
253. Arnardottir HH, Dalli J, Colas RA, Shinohara M, Serhan CN. Aging delays resolution of acute inflammation in mice: reprogramming the host response with novel nano-proresolving medicines. J Immunol. (2014) 193:423544. doi: 10.4049/jimmunol.1401313

254. Hellmann J, Zhang MJ, Tang Y, Rane M, Bhatnagar A, Spite M. Increased saturated fatty acids in obesity alter resolution of inflammation in part by stimulating prostaglandin production. J Immunol. (2013) 191:138392. doi: 10.4049/jimmunol.1203369

255. Luo B, Wang Z, Zhang Z, Shen Z, Zhang Z. The deficiency of macrophage erythropoietin signaling contributes to delayed acute inflammation resolution in diet-induced obese mice. Biochim Biophys Acta Mol Basis Dis. (2020) 1865:339-49. doi: 10.1016/j.bbadis.2018.10.005

256. Tang Y, Zhang MJ, Hellmann J, Kosuri M, Bhatnagar A, Spite M. Proresolution therapy for the treatment of delayed healing of diabetic wounds. Diabetes. (2013) 62:618-27. doi: 10.2337/db12-0684

257. Li S, Sun Y, Liang CP, Thorp EB, Han S, Jehle AW, et al. Defective phagocytosis of apoptotic cells by macrophages in atherosclerotic lesions of ob/ob mice and reversal by a fish oil diet. Circ Res. (2009) 105:107282. doi: 10.1161/CIRCRESAHA.109.199570

258. Khanna S, Biswas S, Shang Y, Collard E, Azad A, Kauh C, et al. Macrophage dysfunction impairs resolution of inflammation in the wounds of diabetic mice. PLoS ONE. (2010) 5:e9539. doi: 10.1371/journal.pone.0009539

259. Cilloniz C, Pantin-Jackwood MJ, Ni C, Goodman AG, Peng X, Proll SC, et al. Lethal dissemination of H5N1 influenza virus is associated with dysregulation of inflammation and lipoxin signaling in a mouse model of infection. J Virol. (2010) 84:7613-24. doi: 10.1128/JVI.00553-10

260. Morita M, Kuba K, Ichikawa A, Nakayama M, Katahira J, Iwamoto $\mathrm{R}$, et al. The lipid mediator protectin D1 inhibits influenza virus replication and improves severe influenza. Cell. (2013) 153:112-25. doi: 10.1016/j.cell.2013.02.027

261. Regidor PA. Covid-19 management with inflammation resolving mediators? Perspectives and potential. Med Hypotheses. (2020) 142:109813. doi: 10.1016/j.mehy.2020.109813

262. Zhao X, Nicholls JM, Chen YG. Severe acute respiratory syndromeassociated coronavirus nucleocapsid protein interacts with smad3 and modulates transforming growth factor-beta signaling. J Biol Chem. (2008) 283:3272-80. doi: 10.1074/jbc.M708033200

263. Park YJ, Liu G, Lorne EF, Zhao X, Wang J, Tsuruta Y, et al. PAI-1 inhibits neutrophil efferocytosis. Proc Natl Acad Sci USA. (2008) 105:117849. doi: 10.1073/pnas.0801394105

264. World Health Organisation. Draft Landscape of COVID-19 Candidate Vaccines. (2020). Available online at: https://www.who.int/publications $/ \mathrm{m} /$ item/draft-landscape-of-covid-19-candidate-vaccines. (accessed August 7, 2020).

265. Callaway E. Coronavirus vaccine trials have delivered their first results - but their promise is still unclear. Nature. (2020) 581:363-4. doi: 10.1038/d41586-020-01092-3

266. Doremalen N, Lambe T, Spencer A, Belij-Rammerstorfer S, Purushotham JN, Port JR, et al. ChAdOx1 nCoV-19 Vaccination Prevents SARS-CoV-2 Pneumonia in Rhesus Macaques. bioRxiv [Preprint]. (2020) doi: 10.1101/2020.05.13.093195

267. Gao Q, Bao L, Mao H, Wang L, Xu K, Yang M, et al. Rapid development of an inactivated vaccine candidate for SARS-CoV-2. Science. (2020) 369:7781. doi: $10.1126 /$ science.abc1932

268. Yu J, Tostanoski LH, Peter L, Mercado NB, McMahan K, Mahrokhian SH, et al. DNA vaccine protection against SARS-CoV-2 in rhesus macaques. Science. (2020). 369:806-11. doi: 10.1126/science.abc6284

269. Moderna. Moderna Announces Positive Interim Phase 1 Data for its $m R N A$ Vaccine (mRNA-1273) Against Novel Coronavirus. (2020). Available online at: https://investors.modernatx.com/news-releases/news-release-details/ moderna-announces-positive-interim-phase-1-data-its-mrna-vaccine (accessed June 17, 2020)

270. Bolles M, Deming D, Long K, Agnihothram S, Whitmore A, Ferris M, et al. A double-inactivated severe acute respiratory syndrome coronavirus vaccine provides incomplete protection in mice and induces increased eosinophilic proinflammatory pulmonary response upon challenge. J Virol. (2011) 85:12201-15. doi: 10.1128/JVI.06048-11
271. Deming D, Sheahan T, Heise M, Yount B, Davis N, Sims A, et al. Vaccine efficacy in senescent mice challenged with recombinant SARS$\mathrm{CoV}$ bearing epidemic and zoonotic spike variants. PLoS Med. (2006) 3:e525. doi: 10.1371/journal.pmed.0030525

272. Sheahan T, Whitmore A, Long K, Ferris M, Rockx B, Funkhouser W, et al. Successful vaccination strategies that protect aged mice from lethal challenge from influenza virus and heterologous severe acute respiratory syndrome coronavirus. J Virol. (2011) 85:217-30. doi: 10.1128/JVI.01 805-10

273. Dorrington MG, Bowdish DM. Immunosenescence and novel vaccination strategies for the elderly. Front Immunol. (2013) 4:171. doi: 10.3389/fimmu.2013.00171

274. Frech SA, Kenney RT, Spyr CA, Lazar H, Viret JF, Herzog C, et al. Improved immune responses to influenza vaccination in the elderly using an immunostimulant patch. Vaccine. (2005) 23:946-50. doi: 10.1016/j.vaccine.2004.06.036

275. Baldwin SL, Hsu FC, Van HN, Gage E, Granger B, Guderian JA, et al. Improved immune responses in young and aged mice with adjuvanted vaccines against H1N1 influenza infection. Front Immunol. (2018) 9:295. doi: 10.3389/fimmu.2018.00295

276. Taylor DN, Treanor JJ, Sheldon EA, Johnson C, Umlauf S, Song L, et al. Development of VAX128, a recombinant hemagglutinin (HA) influenzaflagellin fusion vaccine with improved safety and immune response. Vaccine. (2012) 30:5761-9. doi: 10.1016/j.vaccine.2012.06.086

277. Diaz Granados CA, Dunning AJ, Jordanov E, Landolfi V, Denis $\mathrm{M}$, Talbot HK. High-dose trivalent influenza vaccine compared to standard dose vaccine in elderly adults: safety, immunogenicity and relative efficacy during the 2009-2010 season. Vaccine. (2013) 31:8616. doi: 10.1016/j.vaccine.2012.12.013

278. Falsey AR, Treanor JJ, Tornieporth N, Capellan J, Gorse GJ. Randomized, double-blind controlled phase 3 trial comparing the immunogenicity of high-dose and standard-dose influenza vaccine in adults 65 years of age and older. J Infect Dis. (2009) 200:172-80. doi: 10.1086/599790

279. Izurieta HS, Thadani N, Shay DK, Lu Y, Maurer A, Foppa IM, et al. Comparative effectiveness of high-dose versus standard-dose influenza vaccines in US residents aged 65 years and older from 2012 to 2013 using medicare data: a retrospective cohort analysis. Lancet Infect Dis. (2015) 15:293-300. doi: 10.1016/S1473-3099(14)71087-4

280. Karlsson EA, Beck MA. The burden of obesity on infectious disease. Exp Biol Med. (2010) 235:1412-24. doi: 10.1258/ebm.2010.010227

281. Neidich SD, Green WD, Rebeles J, Karlsson EA, Schultz-Cherry S, Noah TL, et al. Increased risk of influenza among vaccinated adults who are obese. Int J Obes. (2017) 41:1324-30. doi: 10.1038/ijo.2017.131

282. Painter SD, Ovsyannikova IG, Poland GA. The weight of obesity on the human immune response to vaccination. Vaccine. (2015) 33:44229. doi: 10.1016/j.vaccine.2015.06.101

283. Weber DJ, Rutala WA, Samsa GP, Santimaw JE, Lemon SM. Obesity as a predictor of poor antibody response to hepatitis B plasma vaccine. JAMA. (1985) 254:3187-9. doi: 10.1001/jama.1985.03360220053027

284. Karlsson EA, Sheridan PA, Beck MA. Diet-induced obesity impairs the $\mathrm{T}$ cell memory response to influenza virus infection. J Immunol. (2010) 184:3127-33. doi: 10.4049/jimmunol.0903220

285. Kim YH, Kim JK, Kim DJ, Nam JH, Shim SM, Choi YK, et al. Diet-induced obesity dramatically reduces the efficacy of a 2009 pandemic H1N1 vaccine in a mouse model. J Infect Dis. (2012) 205:244-51. doi: 10.1093/infdis/ jir731

286. Park HL, Shim SH, Lee EY, Cho W, Park S, Jeon HJ, et al. Obesityinduced chronic inflammation is associated with the reduced efficacy of influenza vaccine. Hum Vaccin mmunother. (2014) 10:1181-6. doi: 10.4161/h v. 28332

287. Frasca D, Ferracci F, Diaz A, Romero M, Lechner S, Blomberg BB. Obesity decreases B cell responses in young and elderly individuals. Obesity. (2016) 24:615-25. doi: 10.1002/oby.21383

288. Sheridan PA, Paich HA, Handy J, Karlsson EA, Hudgens MG, Sammon $\mathrm{AB}$, et al. Obesity is associated with impaired immune response to influenza vaccination in humans. Int J Obes. (2012) 36:10727. doi: $10.1038 /$ ijo. 2011.208 
289. Karlsson EA, Hertz T, Johnson C, Mehle A, Krammer F, SchultzCherry S. Obesity outweighs protection conferred by adjuvanted influenza vaccination. mBio. (2016) 7:e01144-16. doi: 10.1128/mBio.01 144-16

290. Aiello A, Farzaneh F, Candore G, Caruso C, Davinelli S, Gambino C, et al. Immunosenescence and its hallmarks: how to oppose aging strategically? A review of potential options for therapeutic intervention. Front Immunol. (2019) 25:2247. doi: 10.3389/fimmu.2019.02247

291. Pae M, Meydani SN, Wu D. The role of nutrition in enhancing immunity in aging. Aging Dis. (2012) 3:91-129.

292. Mannick JB, Giudice GD, Lattanzi M, Valiante NM, Praestgaard J, Huang B. mTOR inhibition improves immune function in the elderly. Sci Transl Med. (2014) 6:268. doi: 10.1126/scitranslmed.30 09892

293. Mannick JB, Morris M, Hockey HU, Roma G, Beibel M, Kulmatycki K. TORC1 inhibition enahnces immune function and reduces infections in the elderly. Sci Transl Med. (2018) 10:eaaq1564. doi: 10.1126/scitranslmed.aa q1564
294. Linkage C. COVID-19 Sub-Study. (2020). Available online at: https://www. linkage-camden.com/covid-19-sub-study/ (accessed June 17, 2020).

295. Ford M. Study Explores Why Covid-19 Disproportionately Affects Older People. (2020). Available online at: https://www.nursingtimes. net/news/research-and-innovation/study-explores-why-covid-19disproportionately-affects-older-people-30-04-2020/. (accessed June17, 2020).

Conflict of Interest: The authors declare that the research was conducted in the absence of any commercial or financial relationships that could be construed as a potential conflict of interest.

Copyright (c) 2020 Hazeldine and Lord. This is an open-access article distributed under the terms of the Creative Commons Attribution License (CC BY). The use, distribution or reproduction in other forums is permitted, provided the original author(s) and the copyright owner(s) are credited and that the original publication in this journal is cited, in accordance with accepted academic practice. No use, distribution or reproduction is permitted which does not comply with these terms. 